\title{
WANNPRES 2014 ABSTRACTS Afr J Tradit Complement Altern Med. (2015) 12(S):1-44 http://dx.doi.org/10.4314/ajtcam.v12i5.1S
}

\section{WELCOME ADDRESS:}

\author{
$6^{\text {th }}$ WESTERN AFRICAN NETWORK OF NATURAL PRODUCTS RESEARCH SCIENTISTS (WANNPRES) CONFERENCE \\ AND THE AJTCAM SYMPOSIUM ON AFRICAN TRADITIONAL MEDICINES, 2014.
}

All Protocols dully observed;

I welcome you all to the $6^{\text {th }}$ WESTERN AFRICAN NETWORK OF NATURAL PRODUCTS RESEARCH SCIENTISTS

(WANNPRES) CONFERENCE, on behalf of the local organizing committee and the entire leadership body of this prestigious organization. As an international organization, WANNPRES as a network of scientists is concerned with specific interest in (the) effective use of natural products in the management of both infectious and non-infectious diseases. This Network, officially established in 2002, comprise research scientists drawn from various Universities and Research Institutes within Anglo-andFrancophone countries in West African sub-region and beyond enjoy the membership of fifteen countries as council members. Participants are encouraged to visit WANNPRES official website: www.wannpres.net., for further updates and information on her products, programmes and services.

It would be recalled that the $1^{\text {st }}$ to $5^{\text {th }}$ previous WANNPRES conferences had Ghana, Burkina-Faso and Nigeria as host countries respectively in 2004, 2006, 2008, 2010, and 2012. As for this epoch making $6^{\text {th }}$ international (WANNPRES) conference holding August 3-7, 2014; emphasis is on the sustainable exploration of African medicinal plants and natural products. Also, a special session organized by AJTCAM in commemoration of her $10^{\text {th }}$ Anniversary will be a major highlight devoted to the celebration of African Traditional Medicines. Thus, the theme of this conference: SUSTAINABLE EXPLORATION OF AFRICAN MEDICINAL PLANTS AND NATURAL PRODUCTS FOR DISEASE MANAGEMENT aims at developing the best strategies required for training and education to advance further development of natural products in the treatment of both infectious and non-infectious diseases. Again, the workshops are geared towards the establishment of a collaborative working relationship with herbal practitioners in West Africa with the aim of sharing relevant information with those working in the field in reaching a consensus on the scientists/herbalists inter-phase in areas of interest. Furthermore, possible ways of optimal utilization and conservation of economic medicinal plants will be explored.

It is worthy of note that Nigeria is hosting this WANNPRESS conference for the second time; the first being in 2012. As a result, the local organizing committee poised to improving on possible previous lapses, encountered during the last conference chose Leisure Spring Hotels Ltd., in her attempt at creating a conducive environment for participants to ensure they maximized their stay in Nigeria. In addition, all conferees are encouraged to participate actively in all sessions for optimal benefits. On May 20, 2014, the South West Zone of WANNPRES in Nigeria organized a one-day WANNPRES meeting at the Faculty of Pharmacy, Obafemi Awolowo University, Ile-Ife. Prof. Olatunde Farombi, Dean, Faculty of Basic Medical Sciences, University of Ibadan, gave an invited lecture titled Bioefficacy, Antioxidative and Chemopreventive Properties of Some Nigerian Medicinal Plants and Toxicological Considerations. It was well received.

The Local Organizing Committee is honouring some West African citizens for their various roles in the sustainability of Natural Products with the following awards: i. Award of Excellence in Category, Herbal Drug Production - Rev. Father A. Adodo; ii. Award of Excellence in the Category, Propagation of Natural Products - Aare Afe Babalola, founder, Afe Babalola University, Ado-Ekiti; iii. Award of Excellence in Category: Distinguished Contributions to Sustainable Utilization of Natural Products - Ogbeni Rauf Aregbesola; and iv. Distinguished media award - High Chief R. A. Dokpesi.

While we celebrate with the awardees, we should remember our Late Prof. Marian E. Addy, a founding member and first executive secretary of West African Network of Natural Products Research Scientists (WANNPRES); Chairperson of many Scientific Organizations (Ghanaian and International), Advisory Boards and various profound Committees on Health and Scientific Projects (PCPC, WAHO/WHO/FRO, WABPTEX, etc.); Outstanding International Organizations, of which (WANNPRES), is one of such. She was also on the Editorial Board of the African Journal of Traditional, Complementary and Alternative Medicine, an International Journal domiciled in Nigeria (We rise for a minute silence). May her soul rest in peace. (Amen)

In furtherance of our previous appeal to members on the need for prompt payment of our respective annual dues, it becomes imperative to re-iterate at this juncture that WANNPRES as a non-profit making body must of necessity move beyond her present operational scope to meet its increasing financial obligations. However, a constant reminder to all concerned is not out-of-place, especially as regards WANNPRESS secretariat in connection with each country's chapter dues. The need to provide scholarships and research grants to deserving colleagues for M.Sc., and/or PhD programs through partnerships with either local, foreign or international agencies like DAAD, DANIDA, and WAHO respectively. Again, in pursuance of the conference theme, our well-structured collaborative programmes with Traditional Herbal Practitioners (TMPs) needs to be strengthened, fully embraced by all and supported along individual nation chapters. Please note that according to the 2012 conference report on the non-completion of the proposal writing sent to colleagues as far back as October 2010, still remain an on-going project. However, the proposed amendment of 


\section{WANNPRES 2014 ABSTRACTS Afr J Tradit Complement Altern Med. (2015) 12(S):1-44 http://dx.doi.org/10.4314/ajtcam.v12i5.1S}

WANNPRES constitution, considered at the last AGM meeting has been completed. More so, members are advised to prepare to elect new executive officers as this conference falls within the election year - according to WANNPRESS' calendar.

As part of the programmes designed to make this conference an enduring experience for participants, interested conferees are advised to visit the information desks to register their interests for scheduled field-trips to some historic sites within Osun State and for the conference dinner. I would like to express our profound gratitude to our distinguished guests, sponsors, and thanked all participants from Ghana, Nigeria, Mali, Côte d'ivoire, Cameroon, Benin and Burkina Faso, South Africa and the UK at this challenging period in our time. The challenges include hunger, disease and terrorism etc. I also thank members of the local organizing committee for their respective inputs towards the success of this year's WANNPRES conference. You are hereby encouraged to be part of WANNPRES bi-annual conferences. Let us be part of the initiatives to build a formidable natural products research programmes that will develop, strengthen and enhance all scientific and technological collaborations within sub-Saharan (Africa) and other related global organizations. We look forward to the emergence of some partnership project/programmes during the course of this conference. Of interest is the MUTHI CLINICAL TRIALS WORKSHOP scheduled for the Faculty of Pharmacy Board Room from August $8-12$, 2014. Some of you will be participating at this Workshop. Once again, on behalf of the LOC, I welcome you all to this epoch making event. Enjoy the conference!

Thanks.

Prof. C. O. Adewunmi

Drug Research and Production Unit,

Faculty of Pharmacy,

Obafemi Awolowo University,

Ile-Ife, Nigeria.

Executive Secretary, WANNPRES

August 3, 2014.

\section{ALLOCUTION DE BIENVENUE : \\ VIème CONFÉRENCE OUEST AFRICAINE DE LA RECHERCHE SCIENTIFIQUE SUR LES PRODUITS NATURELS, ET SYMPOSIUM SUR LA MÉDECINE TRADITIONNELLE AFRICAINE.}

Tous protocoles dument observés ;

Au nom du comité local d'organisation et de tout le corps administratif de cette prestigieuse organisation, je vous souhaite à tous, la bienvenue à la Sixième Conférence Ouest Africaine de la recherche scientifique sur les produits naturels (WANNRES. En tant qu'organisation internationale et réseau de chercheurs scientifiques, le WANNARES scrute avec grand intérêt l'utilisation effective des produits naturels pour le traitement à la fois de maladie infectieuse et non-infectieux. Ce réseau qui officiellement inauguré en 2002, comprend en son sein des chercheurs scientifiques venus de plusieurs universités et instituts de recherches dans les sphères francophones et anglophones, de la sous-région ouest africaine, voire au-delà. C'est donc avec joie que ce réseau réunit près de 15 pays, inscrits comme membres de son conseil. Nous invitons les participants à visiter le site officiel du WANNARES : www, wannpres.net. pour plus d'informations récentes sur ses produits, ses programmes et services.

L'on peut pour mémoire évoquer que toutes les précédentes rencontres WANNARES se sont tenues au Ghana Burkina Faso et au Nigéria, respectivement en 2004, 2006 , 2008, 2010 et 20012, de la première conférence jusqu'à la cinquième . Nous sommes donc rendus à ce jour à la sixième conférence qui a lieu du 4 au 7 aout 2014. L'accent y sera mis sur une exploitation suivie des plantes médicinales africaines et des produits naturels. L'on peut aussi annoncer une session spéciale organisé par AJTCAM, pour commémorer son dixième anniversaire, qui marquera un temps fort dans la célébration de la médecine traditionnelle africaine. C'est ainsi que la thématique de cette conférence, EXPLOITATION SUIVIE DES PLANTES MÉDICINALES AFRICAINES ET PRODUITS NATURELS, EN VUE DE TRAITEMENT DES MALADIES, vise à développer la meilleure stratégie adéquate pour l'enseignement et la formation en vue de promouvoir le développement des produits naturels, dans le traitement à la fois de maladies infectieuses et non infectieux. De plus, les sessions d'ateliers offriront l'opportunité de nouer des relations étroites et une collaboration pratique avec les tradi-praticiens de l'Afrique de l'Ouest. L'enjeu majeur sera de partager des informations vitales avec ceux qui travaillent sur le terrain, pour arriver à un consensus, selon le domaine d'intérêt, dans l'interface qui oppose scientifiques et tradi praticiens. En outre, il sera aussi exploré les voies possibles pour optimiser l'utilisation et la conservation des plantes médicinales de rente.

L'on ne devrait pas manquer de souligner, que le Nigéria en est à sa deuxième organisation de la conférence WANNARES après celle de 2012. En effet le Comité Local d'Organisation (CLO), s'est sérieusement penché sur les manquements rencontrés lors de la précédente réunion, pour y apporter les amendements nécessaires. Pour ce faire, le choix du lieu d'hébergement a porté sur le 


\section{WANNPRES 2014 ABSTRACTS Afr J Tradit Complement Altern Med. (2015) 12(S):1-44 http://dx.doi.org/10.4314/ajtcam.v12i5.1S}

Leisure Spring Hotel Ltd. situé à Osogbo, dans un environnement adéquat, fait de charmes, pouvant inciter les participants à étendre leur séjour au Nigéria. Ajouté à cela, tous les conférenciers sont encouragés à participer à toutes les sessions pour en tirer plus profit.

Le 20 mai 2014, La section WANNPRES du sud-ouest au Nigéria a organisé une réunion d'une journée, tenue à Faculté de pharmacie, Obafemi Awolowo University, Ile-Ife. Le Professeur Olatunde Farombi, Doyen de la Faculté des sciences médicales de base, University of Ibadan et invité pour la circonstance, avait présenté une communication sur la Bio-efficacité, les propriétés antioxydatives et chimio préventive contenues dans certaines plantes médicinales au Nigéria, et les considérations toxicologiques.

Le Comité Local d'Organisation, en reconnaissance des rôles importants joués par certains citoyens d'Afrique de l'Ouest dans la recherche persistante sur plusieurs produits naturels, a proposé des distinctions honorifiques selon les catégories suivantes (i) Prix d'excellence dans la production de médicaments naturels - Rev. Père Adodo; (ii) Prix d'excellence dans la dissémination de produits naturels : Aare Afe Babalola, fondateur de Afe Babalola University, Ado Ekiti ; (iii) Prix d'excellence et de distinction de par ses contributions dans l'usage ininterrompu de produits naturels - Ogbeni Rauf Aregbesola ; et (iv) Prix du média - Chef Supérieur R.A. Dokpesi.

Au moment où nous nous réjouissons avec ces illustres distingués, nous avons aussi une pensée pour la mémoire de notre regrettée Professeure Marian E. Addy, un des membres fondateurs du premier secrétariat exécutif pour le réseau de chercheurs scientifiques en Afrique de l'Ouest (WANNPRES) . Présidente d'innombrables organisations scientifiques (Ghanéen et international), présidente de comités consultatifs et de plusieurs comités d'experts sur la santé et projets scientifiques (PCPC, WAHO/WHO/FRO, WABPTEX, etc....), des organisations internationales très réputées dont WANNPRES fait partie. Elle était membre du comité éditorial du journal africain sur la médecine alternative, un journal international basé au Nigéria (Nous vous prions de vous lever et de garder une minute de silence en sa mémoire) ; que son âme repose en paix ! (Amen)

Nous référant à notre précédant vibrant appel aux membres sur la nécessité de s'acquitter promptement de leurs contributions, il est devenu plus qu'urgent à ce point de rappeler que WANNPRES, organisation à but non lucratif, devrait transcender sa situation opérationnelle actuelle pour pouvoir arriver à réunir tous les fonds nécessaires. Cependant ces messages envoyés constamment aux membres à titre de rappel, à cet effet sont de bon augure, surtout qu'il s'agit pour le secrétariat en contact avec tous les pays membres, de gérer des passifs. Bienvenue est aussi, l'idée d'octroyer des bourses de recherche par l'entremise de partenariats avec des agences locales et internationales, DAAD, DANIDA et WAHO, respectivement pour des programmes de Master en Sciences et/ou $\mathrm{PhD}$, à des collègues méritants. Aussi, en se référant à notre thème du débat, notre programme bien structuré, portant sur la collaboration avec les tradi-praticiens (TMP), a bien besoin d'être renforcé avec la participation et le soutien de tous, aux sections de chaque pays. D'après le rapport de la conférence de 2012 sur le caractère inachevé de la rédaction de proposition envoyée aux collègues depuis 2010, prière de noter que le projet demeure en cours. Toutefois les amendements proposés sur la constitution de WANNPRES et pris en considération lors de la précédente réunion générale annuelle (AGM), sont actuellement achevés. Qui plus est, les membres sont avisés de se préparer pour les élections de nouveaux membres du bureau exécutif dans cette même salle de conférence, et ceci tombe bien dans le cadre du calendrier de l'année électorale.

Dans le souci de faire de cette réunion un passage mémorable, nous conseillons aux conférenciers intéressés d'aller au bureau des inscriptions soumettre leur nom, en vue d'une visite sur certains sites historiques dans l'Etat d'Osun et ses environs. Je voudrais saisir cette opportunité pour exprimer notre profonde gratitude à tous, et surtout à nos illustres invités, et sponsors. Je voudrais par la même occasion remercier tous nos participants du Ghana, Nigéria, Mali, Côte d'Ivoire, Cameroon, Benin Burkina Faso, Afrique du Sud et Royaumes unis, qui se sont donnés tant de peines à arriver par ces moments o combien traversés de multiples défis dont, la famine, les maladies, le terrorisme etc. J'exprime ma gratitude aux membres du Comité Local d'Organisation pour leurs apports et contributions au succès de WANNPRES cette année. Vous êtes de ce fait encouragés à prendre part à la conférence biannuelle du WANNPRES. Soyons tous concernés par l'initiative qui consiste à bâtir un époustouflant programme de recherches sur les produits naturels , un programme qui développera, renforcera et donnera un coup de pouce dans toutes collaborations scientifiquetechnologique, de même qu'avec d'autres organismes associés, en Afrique subsaharienne. Nous entrevoyons au cours de cette conférence, une émergence de quelques projets ou programmes en partenariat.

Il est important de souligner que l'Atelier d'Essais Multi Clinique, se tiendra dans la salle des comités de la Faculté de Pharmacie du 8 au 12 aout, 20 14. Certains d'entre vous prendront part à cet atelier. Une fois de plus je vous souhaite tous les bienvenus à ce grand évènement qui marquera le temps.. Passez d'agréables moments !

Merci.

Prof. C.O. Adewunmi

Drug Research and Production Unit, Faculty of Pharmacy

Obafemi Awolwo University, Ile - Ife, Nigéria

Sécrétaire Exécutif, WANNPRES

August 3, 2014 
WANNPRES 2014 ABSTRACTS Afr J Tradit Complement Altern Med. (2015) 12(S):1-44 http://dx.doi.org/10.4314/ajtcam.v12i5.1S

\title{
KEY NOTE ADDRESS
}

\author{
REVERSE PHARMACOLOGY: A NOVEL APPROACH TO DEVELOPING PHYTOMEDICINES \\ Merlin Willcox \\ University of Oxford, UK
}

Conventional methods of drug development require at least 15 years and around $\$ 800 \mathrm{~m}$ to develop a new drug. For the development of standardised phytomedicines, a novel approach is proposed, in four phases. (1) A retrospective treatment outcome study, to establish observational evidence of clinical effectiveness, and to select the herbal medicine associated with the best outcomes. (2) A dose-escalating clinical trial, in patients choosing to take the medicine, to establish safety and the optimal dose. (3) A randomised controlled clinical trial, to test effectiveness compared to standard treatment. (4) Isolation of active compounds (for quality control, standardisation etc). Using this approach, it was possible to develop a new standardised antimalarial phytomedicine in Mali, at a cost of $0.4 \mathrm{~m}$ euros, in 6 years. This process will be described in more detail.

\section{PLENARY LECTURES}

\section{PL-01}

\section{SECONDARY METABOLITES WITH BIOLOGICAL ACTIVITIES FROM SOME CAMEROONIAN MEDICINAL PLANTS}

\author{
Bonaventure T. Ngadjui ${ }^{a}$,Gilbert D.W.F. Kapche ${ }^{\mathrm{b}}$, and Berhanu M. Abegaz ${ }^{\mathrm{c}}$ \\ ${ }^{a}$ Department of Organic Chemistry, Faculty of Science, University of Yaounde I, P.O. Box 812 Yaounde, Cameroon \\ ${ }^{b}$ Department of Chemistry, Higher Teacher Training College, University of Yaounde I, P.O. Box 47 Yaounde, Cameroon \\ ${ }^{c}$ The African Academy of Sciences (AAS) P.O Box 24916-00502, Nairobi, Kenya \\ E-mail: ngadjuibt@yahoo.fr
}

Introduction: The main focus of scientific research in Chemistry in Cameroon is the study of natural products. Our effort in the phytochemical studies of Cameroonian medicinal plants could not have proceeded very well without the assistance of our colleagues in the Biology Department who provided the taxonomic identities and the biological activities of the plants. The selection of the plant material for investigation has been guided by their uses in traditional medicine and availability in the market. For the purpose of this presentation, the plants investigated are grouped into two families: Sapotaceae and Moraceae.

Sapotaceae is a family of plants often characterized by the presence of reddish-brown hairs on the leaves. Sapotaceae species provide economically important products such as latex for chewing gum, hard, durable wood and edible fruits; many plants of the Sapotaceae family have medicinal value for the treatment of many illnesses such as diabetes, fevers, infected wounds, skin lesions, malaria, cancer cells [1, 2]. Phytochemical studies carried out in the Sapotaceae family highlighted the presence of terpenoids as the most important class of compounds. Our investigation on Donella ubanguiensis, Tridesmostermon omphalocarpoides reveal the presence of many pentacyclic triterpenoids [3]. In our programme, intensive investigations are continuing with plant of Moraceae family. Within this family we have carried work mainly on Dorstenia, Morus and Ficus. The genus Dorstenia, represented by about 170 species 


\title{
WANNPRES 2014 ABSTRACTS Afr J Tradit Complement Altern Med. (2015) 12(S):1-44 http://dx.doi.org/10.4314/ajtcam.v12i5.1S
}

worldwide, comprises many plants that are used as anti-snakebite, anti-infection and anti-rheumatism remedies in the medicinal plant therapy of many countries in Africa, Central and South America. The genus is now recognized as a rich source of prenyl and geranylsubstituted coumarins and flavonoids [4]. Morus mesozygia Stapf.(Moraceae) is small to medium-sized tree found in the tropical forests of Africa. The leaves and fruit of M. mesozygia provide food to the Mantled Guereza, a colobus monkey native to tropical Africa, and chimpanzee in West and Central Africa [5]. Traditionally, M. mesozygia is used to cure diabetes, arthritis, rheumatism, malnutrition, debility, stomach disorders, veneral diseases, and pain [6].

Methods: The leaves stem and trunk bark of Donella ubanguiensis, Tridesmostermon omphalocarpoides, Morus mesozygia Stapf. together with the twigs of Dorstenia ssp were collected from different regions of Cameroon and identified by Mr. Nana, a botanist at the National Herbarium, Yaoundé (Cameroon) where specimen are deposited.

The air-dried plant materials were ground into powder and extracted with the mixture of methylene chloride methanol 1/1 followed by pure methanol at room temperature. Evaporation of the solvents under reduced pressure provided extracts which were combined on the basis of the TLC and fractionated into hexane, ethyl acetate and $n$-butanol portions. Each portion (hexane, ethyl acetate and $n$ butanol) was subjected to consecutive column chromatography over silica gel and Sephadex LH-20 to give pentacyclic triterpenoids, arylbenzofuran derivatives, styrenes, coumarins and mainly flavonoids.

Discussion: The isolated flavonoids are mono, di or triprenylated and some of them are geranylated. We have been able to isolate and identified many novel structures with biological properties such as anti-malarial, anti- inflammatory, antimicrobial. Recently, nine new antioxidant and antimicrobial derivatives from the stem bark and leaves of this plant were reported by us [4].

\section{References}

[1] Aubreville, A.Flore du Cameroun,famille des Sapotaceae, Museum Nationald'Histoire Naturelle,Laboratoire de Phanerogami 16, Rue Buffon, Paris 5e, 1, 3-17, 119-121 (1964)

[2] EI Babili F. Bouajila J., Fouraste I.Valentin A., Mauret S., Moulis C. Chemical study, antimalarial and antioxidant activities and cytotoxicity to human breast cancer cells (MCF7) of Argania spinosa, Phytomedicine, 17, 157-160 (2010)

[3] Joumessi A. V. B., Sandjo L. P., Liermann J. C., Schollemeyer D., Kuete V., Rincheval V., Berhanu M. A., Yeboah S. O., Wafo P., Ngadjui B. T., Opatz T. Donellanic acids A-C: new cyclopropanic oleanane derivatives from Donella ubanguiensis (Sapotaceae). Tetrahedron, 68, 4621-4627 (2012).

[4] Ngadjui, B. T. Abegaz, B.M. "The chemistry and pharmacology of the genus Dorstenia (Moraceae)" in studies in Natural Products Chemistry (ed. Atta-Ur-Rahman, Elsevier, Vol 29 Bioactive Natural Products (Part J), pp. $761-805$ (2003).

[5] P. J.Fashing, Int. J. Primatol., 22, 579-609 (2001).

[6] H.M. Burkill, The useful plants of West Tropical Africa: Families M-R; RoyalBotanic Gardens, Kew: Richmond, Vol. 4, p 969(1997).

\section{PL-02}

\section{BIOACTIVE METABOLITES FROM AFRICAN MEDICINAL PLANTS}

\author{
T. A. Olugbade \\ Department of Pharmaceutical Chemistry, Faculty of Pharmacy, Obafemi Awolowo University, Ile-Ife
}

The full exploitation of African medicinal plants in meeting the health needs of its expanding population, oblivious of the Malthusian theory, and against a background of evident poverty, inadequate education and conflict, remains a challenge if not a mirage. The expression of reservation stems from the obvious fact that we are lagging behind in this important race against time. To change the 


\title{
WANNPRES 2014 ABSTRACTS Afr J Tradit Complement Altern Med. (2015) 12(S):1-44 http://dx.doi.org/10.4314/ajtcam.v12i5.1S
}

tide of the trend there must be renewed effort by individual and regional governments to identify, protect and conserve its abundant flora containing a large number of species yet to be discovered, before they are lost to urbanisation, mineral exploration, and ironically, food agriculture. If unchecked, the looming long-term impact of climate change on terrestrial and marine flora and fauna is too dreadful to imagine. On the bright side, there has been a unified focus, by scientists and African governments on the development of the traditional herbal recipes, without necessarily waiting for the knowledge about the chemistry of the bioactive principles. This approach has been promoted by the WHO and emphasis has been placed on proven safety, efficacy and some form of standardisation. However, this is not a substitute for the approach of a systematic activity-directed isolation of secondary metabolites from medicinal plants. World-wide experience in the history of natural products as medicines has shown that the two approaches need not be mutually exclusive and both should be supported by African governments. The latter approach is more demanding in terms of time and scientific input. It could be less rewarding in terms of output but it is certainly the most rewarding approach in terms of discovery of new compounds against emerging diseases and endemic tropical infectious diseases most of which are dynamic in character especially because of potentials for resistance. A literature review of the bioactive principles reported from African medicinal plants indicated chemical principles ranging from simple molecules to very complex ones that are not yet amenable to viable commercial synthesis. Improvement in knowledge of biochemical aetiology of diseases and availability of high-throughput and newer screening models, particularly those based on the role of oxidative stress and ion-channels suggest even the need to re-evaluate plants previously studied but discarded, for chemopreventive or other prophylactic benefits. In addition to the potential discovery of exciting new molecules, it is obvious that more known and perhaps ubiquitous compounds, considered unrewarding in phytochemical research, will provide new leads in the discovery of new drugs. Literature also indicates that the marine plants of Africa have received little attention in terms of investigation for potential bioactive principles.

\section{PL-03}

\section{ECONOMIC EXPLOITATION OF AFRICAN MEDICINAL PLANTS}

\section{Karniyus S. Gamaniel PhD}

\author{
National Institute for Pharmaceutical Research and Development (NIPRD)
}

There is no doubt that medicinal plants, which is the mainstay of herbal traditional medical practice in Africa, can contribute to the strategies for reducing the burden of sickness and death due to diseases. It is pertinent to mention that the two most effective drugs for the treatment of malaria that have been accepted globally namely quinine from the bark of the Peruvian Cinchona tree and artemisinin from the Chinese antipyretic Artemisia аппиа L emerged through herbal traditional medicine. However, the level of development in the African herbal industry today is grossly inadequate and unsatisfactory. Herbal medicines industry is a money spinner that could create jobs and wealth while at the same time provide health and environmental benefits. The World Health Organization (WHO), in 2006, estimated the global demand for medicinal plants to be approximately USD14 billion per annum and a demand growth rate of 15 to $25 \%$ annually. It is estimated that by 2050 the trade will be up to USD 5 trillion.

Despite the increasing global interest and demand for herbal medicines and products, there is very little or no indication that Africa is ready to take advantage of this huge opportunity by exploiting its medicinal plant biodiversity. In Nigeria for instance, the cultivation of herbal medicinal products in all the 774 local government councils has the potential of conservatively providing an estimated 1,000,000 jobs. The internal trade in herbal medicines when fully developed is capable of generating up to \$100 billion annually and creating up to 500,000 jobs. The export potential when adequately developed could generate up to USD2.5 billion per annum or more. The question is, what are the issues that hinder the successful exploitation of the African medicinal plant resources and the growth of the African herbal medicines industry? In this paper, some of the challenges to the growth of the African herbal industry are enumerated and discussed. It is suggested that African researchers must domesticate the process of exploiting the African medicinal plant biodiversity and ensure value addition through product development research and innovations. 


\title{
WANNPRES 2014 ABSTRACTS Afr J Tradit Complement Altern Med. (2015) 12(S):1-44 http://dx.doi.org/10.4314/ajtcam.v12i5.1S
}

\section{PL-04}

\section{VALUATION OF MEDICINAL PLANTS - MAKING THEM COUNT IN GROSS DOMESTIC PRODUCT (GDP) CALCULATIONS IN NIGERIA}

*Ogundipe, Oluwatoyin Temitayo

\author{
Professor of Botany and Director, Academic Planning Unit, University of Lagos, \\ Akoka, Lagos.
}

*Corresponding author: Email: toyin60@yahoo.com, Tel: +2348023201618

Traditional use of plants has been in existence since creation; plants play significant roles in human diet and healthcare needs particularly in developing countries. In Nigeria almost $80 \%$ of its populace depends on medicinal plants for their health care needs. Medicinal plants are one of the crucial components of the contribution biodiversity makes to the society; they provide meaningful inputs for drugs and their loss through extinction could lead to considerable loss to the society. Therefore valuation of the components of biodiversity, such as for medicinal plants in a cost-benefit framework helps to understand how the conservation of biodiversity affects the level of human welfare thus devising a proper public policy for its conservation and sustainable use. The objectives of this study is to understand the current situation, trends and economic value potentials of medicinal plants; to explore better ways of placing value on medicinal plants in realizing their potentials as indices for GDP calculations in Nigeria. The Harzing's Publish and Perish Software was employed to analyze publications on the Google scholar between 2000 and 2014 based on publications relating to medicinal plants in Nigeria. The citation analysis revealed a total of 17 paper(s) from 1 author(s); 14 paper(s) from 2 author(s) and 4 paper(s) from 3 author(s) were published on goggle scholar. In addition, there were no publications relating to the economic status of medicinal plants; placing of monetary values on medicinal plants and medicinal plants and gross domestic product growth in Nigeria. Valuation studies on medicinal plants will signify its economic importance which will help provide a meaningful direction to the policy makers for efficient land use planning. This valuation could contribute immensely to the GDP of Nigeria; on the other hand, the economic and social benefits that accrue from activities relating to the development of medicinal plants can provide the necessary platform for promoting interests in Agricultural economic growth. Nigeria stands to benefit immensely from the global herbal products' market which is estimated to be US\$5 trillion by 2050 . 
WANNPRES 2014 ABSTRACTS Afr J Tradit Complement Altern Med. (2015) 12(S):1-44

http://dx.doi.org/10.4314/ajtcam.v12i5.1S

\title{
AFRICAN TRADITIONAL MEDICINE \\ ATM-01
}

\author{
AFRICAN TRADITIONAL MEDICINES (ATMS): CURES OR CURSES? \\ Odukoya, Olukemi Abiodun \\ Department of Pharmacognosy, Faculty of Pharmacy, University of Lagos, Nigeria
}

Background: Over the years, we have witnessed the promotion of use of Traditional Medicine (TM) after resolutions passed by the World Health Assembly to make health affordable and accessible to the populace all over the world including Africa. People selfmedicate and seek remedies without side effects for common ailments and conditions, such as anxiety, arthritis, colds, coughs, constipation, depression, fever, headaches, infections, insomnia, intestinal disorders, premenstrual syndrome, stress, ulcers, malaria, pain, diarrhoeas, inflammation, hypertension, diabetes, sickle cell anaemia, and weakness; as a means for restoration of health to provide cures. However, with the promotion of herbal medicines and products, there are reported cases of misuse.

Materials and Methods: An ethnobotanical survey was carried by gathering information through literature on the use of medicinal plants and some herbal recipes, their component herbs, their medicinal and other uses, chemical constituents, pharmacological actions and toxicological profile as available in the African continent. Information was also gathered through an integrated approach of using semi-structured questionnaires to interview women that sell and hawk herbal preparations.

Results: The medicinal plants used are components from entire plants, roots, barks, leaves, flowers, seeds and aerial parts from a particular herb or plant species as individual entities, or different herb or plant parts of different species combined, or mixtures of extracts. Dosage forms are as powders, decoctions and concoctions, infusions for oral consumptions, enemas and inhalations, or as paste for topical applications in the different African regions of East, West, North, South and Central African Countries. There is massive influx of imported herbs as against the use of ATMs available to our local circumstances in Nigeria. The use of herbal medicines and liquors is on the increase amongst Nigerian young male adults for body weakness and as an aphrodisiac. Legislation on registration and promotion varied with individual countries recording evidences of misuse.

Conclusion: Some herbs are safe in modest amounts as CURES but they may become toxic at higher doses. The introduction of herbal liquors especially in the Nigerian market and the resultant effect may be associated with increase organ damage in young adults. Thus, ATMs are becoming CURSES to the populace.

\section{ATM-02}

ZHI-BAI-DI-HUANG-WAN, A CLASSIC CHINESE MEDICINAL FORMULA IN RELIEVING MENOPAUSAL SYMPTOMS: A MULTI-CENTRE AND CONTROLLED TRIAL FROM UK AND CHINA

\author{
Fan Qu ${ }^{1,2} * *$, Dan Jiang ${ }^{2 *}$, Jian-Hong Zhou ${ }^{1}$, Jue Zhou ${ }^{3}$, Ying-Er Gu ${ }^{2}$, Dong-Xia Yang ${ }^{4}$, Qing Weng ${ }^{5}$, Yun Li $^{2}$, Bing $^{2}$ \\ Wang ${ }^{2}$, Fang $\mathrm{Yu}^{2}$ \\ ${ }^{1}$ Acu-herb consultant 439 Glossop Road Sheffield S10 2PR UK \\ ${ }^{2}$ Women's Hospital, School of Medicine, Zhejiang University, Hangzhou, Zhejiang 310006, China \\ ${ }^{3}$ College of Food Science and Biotechnology, Zhejiang Gongshang University, Hangzhou, Zhejiang 310012, China \\ ${ }^{4}$ The $2^{\text {nd }}$ Hospital, Heilongjiang University of Chinese Medicine, Harbin, Heilongjiang, 150000 China \\ ${ }^{5}$ The Third People's Hospital of Yuhang District, Hangzhou, Zhejiang, 311115, China
}

*** Corresponding author: Email:qufan43@ outlook.com,Tel: +86 571 87061501; Fax: : +86 57187061501 


\section{WANNPRES 2014 ABSTRACTS Afr J Tradit Complement Altern Med. (2015) 12(S):1-44 http://dx.doi.org/10.4314/ajtcam.v12i5.1S}

Background: To explore the effects of Zhi-Bai-Di-Huang-Wan (ZBDHW), a classic formula of Chinese medicinal herbs in relieving menopausal symptoms in British and Chinese women.

Patients and Methods: Between May 2011 and May 2013, Chinese and British women (224) were divided into a ZBDHW group with 115 cases and a control group with 109 cases. The clinical menopausal symptoms were assessed by the modified Kupperman Index Scale. The serum levels of follicle stimulating hormone (FSH) and estradiol $\left(\mathrm{E}_{2}\right)$ were respectively detected before and after the treatment.

Results: After 12 weeks of treatment, both groups' Kupperman index scores markedly decreased $(P<0.05)$ and no significant difference existed between them $(P>0.05)$. The serum levels of FSH did not change significantly after the treatment $(P>0.05)$ and no significant difference existed between them $(P>0.05)$. The serum levels of $E_{2}$ significantly increased in both of the two groups $(P<0.05)$ and it increased more in the comparison group $(P<0.05)$. No side-effect of the treatment was reported in both of the two groups during the period of the treatment.

Conclusions: The classic Chinese medicinal formula, ZBDHW, showed promise in relieving menopausal symptoms.

Key Words: Chinese medicinal herb; Zhi-Bai-Di-Huang-Wan (ZBDHW); menopausal symptoms

\section{ATM-03}

THE USE OF AFRICAN PLANTS TO MANAGE ANIMAL DISEASES AND PROMOTE ANIMAL PRODUCTIVITY Jacobus (Kobus) N Eloff

Phytomedicine Programme, Faculty of Veterinary Science, University of Pretoria, South Africa

Background: Most work on medicinal plants to date has focused on human health with the aim of identifying new pharmaceutical compounds. There has been some success in human diseases such as cancer and diabetes, but hardly any success on antimicrobial or antiparasitic aspects. The selection of plant species to investigate was usually based on traditional use. Because food security becomes more important with global warming-induced climate changes, many groups all over the world have started investigating the use of plants to increase animal productivity by managing animal disease. There is a tremendous problem with the development of resistance of microorganisms, internal and external parasites against commercial products. The hypothesis is that commercially useful products can be developed from plants

Methods: In our experience plants selected based on traditional use for antimicrobial application had no higher activity than plants randomly selected. We have screened leaf extracts of more than 600 tree species against six bacterial and two fungal pathogens. We have used a range of methods depending on the application.

Results: A crude extract selected from this database was as active as the current commercial product in protecting poultry against Aspergillus fumigatus infections. We were also able to establish a plant-based product that was better than gentamycin in protecting animal wounds from topical infections. Work on replacing antibiotic feed additives with plant extracts gave varying results. On the other hand traditional leads were very useful when we developed products to treat diabetes, to protect animals against fly larvae that cause myiasis and to protect animals against ticks. Substantial work with varying success was also done on treating helminth infections and investigating diarrhoea in animals.

Conclusion: In many cases the crude extracts had activities close to that of the isolated compounds. It appears that using plant extracts therefore is a much more feasible approach than using the active compounds.

Acknowledgement: This work reports on the results of many students. 


\title{
WANNPRES 2014 ABSTRACTS Afr J Tradit Complement Altern Med. (2015) 12(S):1-44 http://dx.doi.org/10.4314/ajtcam.v12i5.1S
}

ATM-04

\author{
ANTI-INFLAMMATORY HERBS AND THEIR MOLECULAR MECHANISMS OF ACTION \\ Chukwuemeka Sylvester Nworu \& Peter Achunike Akah \\ Department of Pharmacology \& Toxicology, Faculty of Pharmaceutical Sciences, University of Nigeria, Nsukka
}

Background: A large number of studies have shown that anti-inflammatory activities of herbal extracts and herb-derived compounds are mainly due to their inhibition of arachidonic acid (AA) metabolism, cyclo-oxygenase (COX), lipo-oxygenase (LOX), proinflammatory cytokines, inducible nitric oxide, and transcription activation factor (NF- $\mathrm{kB})$.

Method: This paper attempts to review some anti-inflammatory herbs and their molecular mechanisms of action.

Results: Some anti-inflammatory medicinal herbs are reported to stabilize lysosomal membrane and some cause the uncoupling of oxidative phosphorylation of intracellular signalling molecules. Many have also been shown to possess strong oxygen radical scavenging activities. Most of these mechanisms are related and many herbal products have been shown to act through a combination of these molecular pathways. Interestingly, many of these herbs lack the gastro-erosive side effects of non-steroidal anti-inflammatory drugs (NSAID) or the plethora of unwanted side effects associated with steroidal anti-inflammatory drugs.

Conclusion: Medicinal plant and plant products have shown tremendous potentials and are used beneficially in the treatment of inflammation and in the management of diseases with significant inflammatory components.

\section{ATM-05}

\section{ETHNOVETERINARY RESEARCH IN NIGERIA: TREND, CHALLENGES AND PROSPECTS}

\author{
Sunday E. Atawodi, PhD., MAAAS, MNYAS., FUICC., FCAI., FAS \\ Biochemistry Department, Ahmadu Bello University, Zaria,
}

*Corresponding author: E-mail: atawodi_se@ yahoo.com, Tel: 08033850613

Background: Most of the animal protein consumed in Nigeria is from the extensive farming system, which in most cases include nomadic pastoralism where access to orthodox medicine is highly limited. Therefore, in Nigerian traditional animal health and production, plants are important components of healthcare delivery as many plants are used to treat and manage diseases from simple stomach disorders to other ailments like trypanosomiasis, dermatophilosis, viral infections etc.

Methods: This paper summarizes the result of ethnoveterinary survey and ethnoveterinary evaluations in our laboratory, and also provides a concise critical review of ethnoveterinary research and practices in Nigeria as available on the internet-accessible peerreviewed journals.

Results: Whereas there are many reports on ethnoveterinary practices as they affect protozoal and parasitic diseases like trypanosomiasis which are of zoonotic significance, reports on other diseases like viral infections are rather scanty. Besides, most of the plants reported to be of use in Nigerian ethnoveterinary practice have not been studied in detail with respect to their active principles and pharmaco-toxicological properties.

Discussion: Despite the different climatic types that encourage diverse vegetation and rich ethno-botanical resources as well as a vibrant and enthusiastic academic community, the scale and especially, the quality of research on ethnoveterinary in Nigeria has remained relatively low due to poor funding, inadequate facilities and lack of sustainability. Considering the importance of 10 
WANNPRES 2014 ABSTRACTS Afr J Tradit Complement Altern Med. (2015) 12(S):1-44

http://dx.doi.org/10.4314/ajtcam.v12i5.1S

ethnoveterinary practices in animal healthcare delivery of many sub-Saharan African countries, the need for government at all levels and for other stakeholders to invest in this worthwhile, albeit expensive and elaborate business is stressed.

Key words: Ethnoveterinary research, Nigeria, challenges, prospects 
WANNPRES 2014 ABSTRACTS Afr J Tradit Complement Altern Med. (2015) 12(S):1-44 http://dx.doi.org/10.4314/ajtcam.v12i5.1S

\title{
ORAL PRESENTATIONS
}

OP-01

\section{BIOACTIVITY-GUIDED APHROSIDIAC POTENTIAL OF MOMORDICA CHARANTIALINN}

\author{
Anselm Adodo ${ }^{1}$ and Adedokun Segun ${ }^{2}$ \\ ${ }^{\text {I}}$ OSB: Coordinator, Pax Herbal Clinic \& Research Laboratories, Edo State. \\ ${ }^{2}$ Dept. of Pharmacognosy, University of Benin, Edo State.
}

Background: In addition to many researches that have been done on Momordica charantia Linn, the ethnopharmacological claim of this plant in the treatment of male sexual dysfunction was investigated in this research.

Materials and Methods: The aerial part of the plant was extracted with ethanol (95\%) using Soxhlet apparatus. Acute toxicity study of the crude extract was carried out at $1000-10,000 \mathrm{mg} / \mathrm{kg}$, followed by in vivo aphrodisiac assay using method of Amin et al., (1996), as well as in vitro lipid peroxidation assay at doses of 100 to $500 \mathrm{mg} / \mathrm{kg}$ and concentrations of 100 to $500 \mathrm{mg} / \mathrm{mL}$ respectively. The extract was partitioned into hexane, chloroform and aqueous fractions. In vivo and in vitro aphrodisiac assays were performed on all the solvent fractions using Sildenafil citrate $(4.8 \mathrm{mg} / \mathrm{kg}$ ) as the positive control. The most active fraction ( $n$-hexane) was subjected to vacuum liquid chromatography (VLC) and other chromatographic procedures using combinations of $n$-hexane, chloroform and ethyl acetate and monitored by lipid peroxidation assay.

Results: Acute toxicity results revealed that the extract is well tolerated as no death was recorded at the highest dose of $10 \mathrm{~g} / \mathrm{kg}$. The extract showed dose dependent increase in mount, intromission and ejaculation frequencies of the crude extract with $66.24 \pm 6.92$, $51.60 \pm 3.80$ and $7.20 \pm 1.50$ respectively. Both mount and intromission frequencies were significantly $(\mathrm{p}<0.05)$ higher than sildenafil citrate with values of $51.00 \pm 6.25$ and $39.40 \pm 2.18$ respectively. Also, testosterone concentrations in the blood of the animals were observed to increase with a value of $7.47 \pm 0.02 \mathrm{ng} / \mathrm{mL}$ at $500 \mathrm{mg} / \mathrm{kg}$ crude extract compared to $4.07 \pm 0.07 \mathrm{ng} / \mathrm{mL}$ obtained for sildenafil citrate. The $n$-hexane fraction showed the highest activity over other solvent fractions. The extract at $500 \mathrm{mg} / \mathrm{mL}$ had the highest effect in lipid peroxidation assay in a manner similar to the in vivo aphrodisiac activity. Column chromatography of bioactive VLC bulked fraction C resulted in the isolation of compound X $(50.35 \mathrm{mg})$ with $\mathrm{R}_{\mathrm{f}} 0.27$ in hexane-ethyl acetate (2:3) using silica gel $\mathrm{GF}_{254}$. In vitro lipid peroxidation assay of the compound $(10 \mathrm{mg})$ showed a similar reduction in lipid peroxidation of PUFA at rate compared to $25 \mathrm{mg}$ of Vitamin E. Spectroscopic analyses suggested the identity of the compound as 13, 14-epoxyoleanan-3-ol-acetate.

Conclusion: The results justified probable use of Momordica charantia in the treatment of male sexual dysfunction and low sperm count.

\section{OP-02}

ANTI-TUBERCULAR GLYCOLIPIDS FROM THE LEAVES OF STERCULIA SETIGERA DEL. (STERCULIACEAE)

\author{
Ibrahim T. Babalola ${ }^{1}$, Esther A. Adelakun ${ }^{2 *}$ and Scott G.Franzblau ${ }^{3}$ \\ ${ }^{I}$ Dept. of Chemistry, Faculty of Natural Sciences, Yobe State University, PMB 1144 Damaturu, Nigeria \\ ${ }^{2}$ Dept. of Chemistry, Faculty of Natural Sciences, University of Jos, Jos, Nigeria \\ ${ }^{3}$ Institute for Tuberculosis Research, College of Pharmacy, University of Illinois at Chicago, \\ 833South Wood Street Chicago, IL 60612, United States.
}

Background: Natural products form a rich source in the search for new anti-tubercular (TB) agents with many groups undertaking screening of natural products as a preliminary step to finding new lead compounds. 


\section{WANNPRES 2014 ABSTRACTS Afr J Tradit Complement Altern Med. (2015) 12(S):1-44 http://dx.doi.org/10.4314/ajtcam.v12i5.1S}

Methods: The anti-TB activity of the leaves of Sterculia setigera, a medicinal plant in Nigeria, was investigated by bioactivity-guided fractionation against virulent strains of Mycobacterium tuberculosis $\left(\mathrm{H}_{37} \mathrm{Rv}\right.$ (ATCC27294)) in vitro, using the Alamar Blue Assay.

Results: Repeated purifications of the active fractions using combination of normal and reverse phase chromatography led to the isolation of a pure fraction with an interesting anti-TB activity (minimum inhibitory concentration of $15.13 \mu \mathrm{g} / \mathrm{ml}$ ). The cytotoxicity of this compound was evaluated against African green monkey kidney cells (Vero cells) and human hepatocellular carcinoma (HepG2) cell lines and were found non-toxic to both cell lines ( $\mathrm{IC}_{50} 102.4$ and $81.08 \mu \mathrm{g} / \mathrm{ml} \mathrm{respectively).}$

Conclusion: Preliminary spectroscopic studies showed that the most active fraction is a mixture of two closely related glycolipids $\left({ }^{1} \mathrm{H}\right.$, ${ }^{13} \mathrm{C}$ NMR). Further purification of the mixture is ongoing to separate them for complete individual structure elucidation. This preliminary report provides a scientific evidence for the presence of glycolipids as the antimycobacterial agent in S. setigera leaves. This is the first report on the occurrence of biologically active glycolipids from S. setigera leaves.

Keywords: Ethnopharmacology, antimycobacterial activity, Sterculia setigera, Natural Products, glycolipids, Drug discovery.

\section{OP-03}

\section{COMPOSITION OF ESSENTIAL OIL OF ARTEMISIA ANNUA L.(ASTERACEAE) CULTIVATED IN PLATEAU} STATE, NIGERIA.

\section{Byencit Binbong, Ajiji M. Izang and Esther A. Adelakun*. \\ Department of Chemistry, University of Jos, Jos. Nigeria.}

Background: Artemisia annua L.(Asteraceae) is an annual herb native of Asia. It is also commonly known as annual or sweet wormwood or Quighao. A. Аnпиa is the major source of artemisinin, an important plant derived drug for the treatment of chloroquineresistant and cerebral malaria. The increasing demand for artemisinin by the pharmaceutical industry has been a driving force for increased cultivation of A. аппиа. Consequently, many countries, particularly in malaria endemic areas, have shown interest in the cultivation of Artemisia annua and Nigeria is one of such countries. The University of Jos, through the Step B Project, has invested in the cultivation of A. аппиа on a large scale in the farmland acquired at Langtang, Plateau State.Although the A. annua plantation is primarily for the production of artemisinin, as part of our studies on the chemical composition of essential oil from $A$. annua grown in Langtang area of PlateauState, this present study is aimed at finding out the effect of change in climatic conditions on the qualitative and quantitative composition of A. аппиа essential oil.

Methods: Artemisia аппиа oil was obtained by hydro distillation of the air-dried leaves of the plant in the pre-flowering stage and the $n$-hexane extract of the leaves obtained by percolation were analyzed by gas chromatography-mass spectrometry.

Results: The oil obtained by hydro distillation gave twenty-five compounds with camphor(10.72\%),copaene(5.83\%), 3 (10)-caren-2$\mathrm{ol}(4.83 \%)$,farnesene $(3.75 \%)$ and arteannuic acid $(2.23 \%)$ as the major terpene components. From the $n$-hexane extract,camphor(19.37\%), aromadendrene(8.17\%),farnesene(5.99\%),1,8-cineole(1.87\%), selinene(1.54\%), artemisia ketone(1.42\%) and camphene $(0.95 \%)$ were the major terpenes identified.

Conclusion: The results of this study showed that the Artemisia annua planted in Langtang is of the stock of the chemo type which produces camphor as the major terpenoid of the essential oil. The results also revealed fewer number and lower quantities of terpenoids in the essential oil, which may be due to the different climatic conditions in Langtang in Nigeria and the Asian countries. 
WANNPRES 2014 ABSTRACTS Afr J Tradit Complement Altern Med. (2015) 12(S):1-44 http://dx.doi.org/10.4314/ajtcam.v12i5.1S

\title{
OP-04
}

POLYMERISATION INHIBITORY AND RADICAL SCAVENGING PROPERTIES OF SELECTED MEDICINAL PLANTS AND ISOLATION OF PSYCHORUBIN FROM THE WHOLE PLANT OF MITRACARPUS VILLOSUS (DC).

\author{
Opeyemi Ayoade, Christianah A. Elusiyan and Felix O. Olorunmola \\ Drug Research and Production Unit, Faculty of Pharmacy, Obafemi Awolowo University, Ile-Ife.
}

Corresponding author: E-mail: bimbola2009@gmail.com

Background: Sickle cell disorder (SCD) is most prevalent in Africa and an estimated 25\% of people living with SCD are found in Nigeria. In continuation of the on-going research efforts of the DRPU at screening medicinal plants with potential antisickling properties, the present study evaluates the antisickling and antioxidant properties of the nine selected plants.

Method: Nine selected plants belonging to five families including leaves of Senna siamea Lam, aerial parts of Lantana camara Linn, Emilia coccinea Sims, Amaranthus viridus Linn, A. hybridus, A. spinosus, flower of Lagenaria breviflora Benth., fruits of Citrulluslanatus sub sp mucosospermus Thum. and whole plant of $M$. villosus (MVW) were collected authenticated. The methanolic extracts were assessed following a time course monitoring of the rate of inhibition of polymerisation of heamolysate HbS molecules treated with sodium metabisulphite and absorbances values were measured using a spectrophotometer at 700nm. Antioxidant property was determined by the 1, 1-diphenyl-2-picrylhydrazyl (DPPH) free radical scavenging bioautography and by the measurement of absorbance at $517 \mathrm{~nm}$ using a spectrophotometer. Isolation and purification of compounds from MVW was performed by chromatographic procedures. Structure of the isolated compound was determined by NMR $\left({ }^{1} \mathrm{H}\right.$ and $\left.{ }^{13} \mathrm{C}\right)$ and by comparison with literature data.

Result: The time-dependent quantitative estimation of the polymerization inhibitory effect of MVW (98.02\%) at 180 secs and at the test dose of $4 \mathrm{mg} / \mathrm{ml}$ was most significant among the extracts screened. Its DPPH radical scavenging capacity was found to be $90.71 \%$ compared to ascorbic acid (98.52\%) at the concentration of $0.781 \mathrm{mg} / \mathrm{ml}$. The chemical studies of MVW lead to the isolation of a naphthoquinone - psychorubrin and three other yet to be identified compounds.

Conclusion: MVW exhibited both strong polymerisation inhibitory and radical scavenging effects. Psychorubrin had a very strong antioxidant property (instant discoloration) in the DPPH bioautography. The antisickling effect and the quantitative estimation of its radical scavenging property are on-going.

\section{OP-5}

\section{ANTIMICROBIAL CONSTITUENTS OF SORGHUM BICOLOR(L.) MOENCH LEAF SHEATH}

\author{
A. O. Oriola ${ }^{1 *}$, O. H. Ogundele ${ }^{2}$, G. O. Onawunmi ${ }^{2}$ and A. O. Ogundaini ${ }^{3}$ \\ ${ }^{I}$ Department of Pharmacognosy, Faculty of Pharmacy, ObafemiAwolowo University, Ile-Ife. \\ ${ }^{2}$ Department of Pharmaceutics, Faculty of Pharmacy, ObafemiAwolowo University, Ile-Ife. \\ ${ }^{3}$ Department of Pharmaceutical Chemistry, Faculty of Pharmacy, ObafemiAwolowo University, Ile-Ife. \\ *Corresponding author: Email: aooriola@gmail.com; Tel.: +2348060531388.
}

Background: Useful antimicrobial agents have been isolated from plant sources. Some of these agents are phenolic acids, polyphenols etc. and may exist as dyes in some higher and lower plants. Sorghum bicolor leaf sheath, commonly called "Sorghum" is 14 


\title{
WANNPRES 2014 ABSTRACTS Afr J Tradit Complement Altern Med. (2015) 12(S):1-44 http://dx.doi.org/10.4314/ajtcam.v12i5.1S
}

used ethnomedicinally in Nigeria for the treatment of infections and production of sorghum-based products such as dyes and waxes. Sorghum has been reported to prevent oxidative stress and serve as potential food drug for the prevention or treatment of degenerative diseases and microbial infections. The study was aimed at evaluating the leaf sheath extracts and the extracted dye of S. bicolor for antimicrobial activity.

Method: The dye (SBD), $1 \% \mathrm{HCl}$ in $50 \% \mathrm{EtOH}(\mathrm{SBA})$ and $50 \%$ EtOAc-MeOH (SEM) crude extracts were evaluated for antimicrobial activity using the cup-plate method. Activity-directed fractionation of SBD $(5 \mathrm{~g})$ and SEM (7 g) extracts resulted in the isolation of four compounds: $(\mathbf{1} ; 500 \mathrm{mg}),(2 ; 88 \mathrm{mg}),(\mathbf{3} ; 112 \mathrm{mg})$ and $(\mathbf{4} ; 234 \mathrm{mg})$ respectively. The isolated compounds were evaluated for antibacterial activity against Bacillus subtilis, using TLC bioautography.

Results: The crude extracts demonstrated activity against B. subtilis, thus, warranting their purification. Compound $\mathbf{4}$ demonstrated the best activity of the four compounds and was characterised as 7-methoxyflavanoid-apigenidin adduct.

Conclusion: The isolated compound that demonstrated antibacterial activity may be responsible in part for the activity of the crude extract.

Key words: Phenolic acids, Sorghum bicolor, B. subtilis, TLC bioautography.

\section{OP-6}

\author{
EVALUATION OF THE EFFECT OF SPATHODEA CAMPANULATA FLOWER BUD EXUDATE ON \\ CATARACTOGENESIS IN RAT LENSES \\ ${ }^{1}$ Adio Gbemisola I., ${ }^{2}$ Faluyi J.O and ${ }^{3}$ Osoniyi $O$. \\ ${ }^{1}$ Department of Biochemistry, Obafemi Awolowo University, Ile-Ife \\ ${ }^{2}$ Department of Botany, Obafemi Awolowo University, Ile-Ife \\ ${ }^{3}$ Department of Biochemistry, Obafemi Awolowo University, Ile-Ife
}

"Corresponding author: Email: adio.gbemisola@yahoo.com; Tel: +2347030952226

Introduction: The flower bud exudate of Spathodea campanulata is commonly employed as a local eye drop in Nigeria and is anecdotally claimed to improve vision. This study evaluated the anticataract activity of Spathodea campanulata (SPCM) flower bud exudate against cataractogenesis using rat lenses. This was with a view to providing empirical scientific support for the use of the exudate of SPCM in the treatment and management of eye disorder.

Method: Lenses were incubated in artificial aqueous humor (Normal control) with simultaneous incubation in 30mM galactose (Cataract induced group). Co-incubation with captopril (Captopril treated group); $0.1 \mathrm{mg} / \mathrm{ml}$ of the exudate (Lower dose treated group) and $0.2 \mathrm{mg} / \mathrm{ml}$ of exudate (Higher dose treated group) constituted the studied groups. After $72 \mathrm{~h}$ of incubation, lenses were observed for cataract and the preventive potential of the exudate against cataractogenesis was evaluated by determining the levels of anti-oxidant parameters such as total protein (TP), glutathione (GSH), malondialdehyde (MDA) and activities of superoxide dismutase (SOD) and catalase (CAT) were evaluated in the lens homogenates.

Results: Photographic evaluation of the lenses showed the development of cataract in the cataract-induced group while higher dose and captopril treated-lenses were able to retard the progression of opacification and only slightly by the lower dose treated lenses. Significant decreases in the levels of GSH and total protein reduction in SOD and CAT activities as well as increase in MDA content in cataractous lenses were observed when compared with the normal control. The SPCM displayed a dose-dependent anticataract activity with captopril showing comparable anticataract potential which increased to $75.55 \%, 64.08 \%$ and $72.45 \%$ of the normal control value in GSH, SOD and CAT activity against $57.7 \%, 76.69 \%$ and $80.61 \%$ respectively in the higher dose treated lenses. 
WANNPRES 2014 ABSTRACTS Afr J Tradit Complement Altern Med. (2015) 12(S):1-44 http://dx.doi.org/10.4314/ajtcam.v12i5.1S

Conclusion: The study concluded that that exudate of SPCM elicited its anticataract potential through its anti-oxidant activities.

\title{
OP-07
}

HEALTH RISK ASSOCIATED WITH PESTICIDE RESIDUES IN LEPTADENIA HASTATA (PERS.) DECNE USED AS A MEDICINAL AND ALIMENTARY PLANT IN BURKINA FASO

\author{
Sylvain ILBOUDO ${ }^{1,2}$, Noya SOME ${ }^{1}$, Richard OUEDRAOGO ${ }^{1,2}$, Nicole J. GUISSOU², Sylvin OUEDRAOGO ${ }^{1}$, Adama M. \\ TOE $^{1}$, Innocent P. GUISSOU ${ }^{1,2}$. \\ ${ }^{1}$ Institut de Recherche en Sciences de la Santé/Centre National de la Recherche Scientifique et Technologique (IRSS/CNRST), 03 \\ BP 7192 Ouagadougou 03, \\ ${ }^{2}$ Laboratoire de Toxicologie, Environnement et SantélEcole Doctorale de la Santé; Université de Ouagadougou, 03 BP 7021
}

Background:Leptadenia hastata (Pers.) Decne is widely used traditionally for hypertension, catarrh, skin diseases, wound-healing, prostate complaints and as an aphrodisiac. It provides food security during seasonal changes in many areas including Sahelian region of Burkina Faso. However, pesticides use for locust control leads to non-selective contamination of environment components as plants. Thus this study determined the level of pesticide residues in L. hastata.

Methods: Gas Chromatography (GC) was used to determine pesticide residues in L. hastata samples collected from six locust outbreak areas of Burkina Faso. The risk quotient method coupled with probabilistic risk assessment model was used for health risk assessment of pesticide detected in the plant samples.

Results: Seven of ten (70\%) researched pesticides were detected in plant samples at content ranging from 0.11 to $2.22 \mathrm{mg} / \mathrm{kg}$. Up to five pesticide residues were detected in some samples. General population is therefore exposed to these pesticides through food intake and in the medicinal uses of L. hastata. The findings suggest that pesticides used for locust control purposes are potential hazard for both medicinal and alimentary use of $L$. hastata. Moreover, the risk is particularly worrisome for infants and young children.

Conclusion: Cautious or restrictive use of these agrochemicals in the Sahelian context is recommended. Furthermore, systematic control of pesticides and other environmental pollutants as heavy metal in medicinal herbal must be implemented for a safe use.

Key Words: Burkina Faso, chemical analysis, health risk, Leptadenia hastata, pesticide residues.

\section{OP-08}

PHYTOCHIMIE ET PROPRIETES ANTHELMINTHIQUES DU DECOCTE AQUEUX DE SABA SENEGALENSIS (A.DC) PICHON (APOCYNACEAE) CONTRE LES VERS ADULTES ET LES DE HAEMONCHUS CONTORTUS

\author{
M. B. Belemlilga ${ }^{1,2}$, A. Traore ${ }^{1}$, S. Ouedraogo ${ }^{1}$, A. Kabore ${ }^{3}$, H. H. Tamboura ${ }^{3}$ et I. P. Guissou ${ }^{1,2}$. \\ ${ }^{I}$ Institut de Recherche en Sciences de la Santé (IRSS/CNRST), département Médecine et PharmacopéeTraditionnelles - Pharmacie \\ (MEPHATRA-PH), 03 BP 7192 Ouaga 03, Burkina Faso \\ ${ }^{2}$ Ecole Doctorale de Santé, URF/SDS, Université de Ouagadougou, BP 7021, Burkina Faso \\ ${ }^{3}$ Institut de l'Environnement et de Recherches Agricoles(INERA/CNRST), Département ProductionsAnimales, Ouagadougou, Burkina \\ Faso. \\ E-mail : $\underline{\text { medilga@yahoo.fr }}$
}




\title{
WANNPRES 2014 ABSTRACTS Afr J Tradit Complement Altern Med. (2015) 12(S):1-44 http://dx.doi.org/10.4314/ajtcam.v12i5.1S
}

Introduction: Saba senegalensis (A.DC) Pichon (Apocynaceae) est utilisée au Burkina Faso pour le traitement les parasites gastrointestinaux. Le décocté aqueux lyophilisé des feuilles de la plante a fait l'objet d'études phytochimique, toxicologique et d'essais anthelminthiques in vitro.

Méthodes: Le matériel végétal est constitué de feuilles de Saba senegalensis et le matériel animal de souris mâles de souche NMRI, des rats adultes de souche WISTAR et de vers adultes d'Haemonchus contortus (H.C).

Le screening phytochimique à été réalisé selon la méthodes de Ciuleiet al.(1982). La toxicité générale aiguë a été évaluée par voie orale et intra péritonéale (i.p) par la méthode de Lichtfield J.F. et Wilcoxon F.A (1949) et ses adaptations successives. Les tests parasitologiques ont été menés sur des vers adultes deH.C. mis en contact avec des concentrations croissantes de l'extrait. Les tests sur organe isolé ont consisté à évaluer l'effet de l'extrait sur les contractions de base et sur le spasme provoqué par un agent contracturant sur le duodénum isolé de rat.

Résultats: Le screening phytochimique a révélé la présence de tanins, de saponosides, de composés réducteurs, d'oses, des anthocyanosides, de glucosides stéroïdiques et triterpéniques, de coumarines et dérivés.

L'étude de la toxicité aiguë chez la souris a révélé que par voie orale, l'extrait est faiblement toxique. La dose létale 50\% par voie i.p a été de $198.59 \mathrm{mg} / \mathrm{kg}$.

L'étude in vitro a montré que le décocté aqueux des feuilles de $S$. senegalensis, a présenté un effet parasiticide concentrationdépendant sur les vers adultes et un effet ovicide sur les œufs d' H.C.

Le décocté aqueux de S. senegalensis a provoqué une contraction concentration-dépendante du duodénum isolé de rat. Cette activité contracturante est inhibée par l'atropine, ce qui montre que le décocté aqueux des feuilles de S. senegalensis aurait un mode d'action anthelminthique de type cholinergique.

Conclusion: Saba senegalensis (A.DC) PICHON posséderait ainsi des propriétés anthelminthiques qui justifient son utilisation en médecine traditionnelle pour les soins antiparasitaires.

Key Words: Saba senegalensis- Phytochimie - Toxicité aiguë - Haemonchus contortus - Antiparasitaires - In vitro.

OP-09

EVALUATION OF THE MORINDA LUCIDA AND TRIDAX PROCUMBENS FOR ANTITRYPANOSOMAL POTENTIAL SINGLY AND IN COMBINATION IN INFECTED MICE

\author{
Abubakar A. ${ }^{*}$, Okogun J. I. ${ }^{2}$, Gbodi T. A. ${ }^{3}$, Kabiru, Y. A ${ }^{4}$, Makun, H. A ${ }^{4}$ and Ogbadoyi E. O. ${ }^{4}$

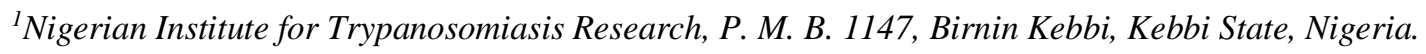 \\ ${ }^{2}$ Department of Traditional Medicine and Medicinal Plant Research, National Institute for Pharmaceutical Research and \\ Development, Abuja, Nigeria. \\ 1. Department of Biochemistry, Ibrahim Badamosi Babaginda University, Lapai, Niger State, Nigeria. \\ 4. Global Institute for Bioexploration, Federal University of Technology, Minna/Department of Biochemistry, Federal University of \\ Technology, Minna, Niger State, Nigeria. \\ *Corresponding Author: (abukadir2@gmail.com)
}

Background: A major problem bessetting the chemotherapy of African Trypanosomiasis is parasite resistance to the few available drugs. One major benefit of combination therapies therefore is that they reduce development of drug resistance, since a pathogen is less likely to have resistance to multiple drugs. 


\title{
WANNPRES 2014 ABSTRACTS Afr J Tradit Complement Altern Med. (2015) 12(S):1-44 http://dx.doi.org/10.4314/ajtcam.v12i5.1S
}

Method: This study explored the potentials of antitrypanosomal activities of Tridax procumbens and Morinda lucida and their combination at the dosage ratio of 1:1, 1:2 and 2:1. All treatments are by i. p. route and commenced after the establishment of infection.

Results: The methanol extract of $M$. lucida stem bark and leaves gave significant mean survival of $7.0 \pm 3.3$ and $9.7 \pm 3.7$ days respectively when compared to the untreated control $(\mathrm{P}<0.05)$. The ethyl acetate and methanol extracts of T. procumbens gave a mean survival of $11.7 \pm 5.4$ and $14.3 \pm 10.2$ days respectively $(\mathrm{P}<0.05)$. The combination of Tridax procumbens and leaves of Morinda lucida methanol extracts at 1:2 gave significant means survival of $10 \pm 2.2$ days $(\mathrm{P}<0.05)$ at $200 \mathrm{mg} / \mathrm{kg}$ body weight, while the least was when combined in ratio 1:1. Phytochemical screening revealed the presence of steroids, saponins, tannins, alkaloids, flavonoids, phenols and carbohydrate in the crude methanol extract and phenols, flavonoids and steroids in the crude ethyl acetate extract of $T$. procumbens.

Conclusion:The methanol extracts of the two plants possess some potential and when combined can act synergistically as antitrypanosomal drug combination to overcome the problem of parasite resistance to conventional drugs.

\section{OP-10}

\section{PROPHYLACTIC EFFECT OF AQUEOUS AND METHANOLIC EXTRACTS OF ANDROGRAPHIS PANICULATAON TRYPANOSOMA BRUCEI BRUCEIINFECTED MICE}

\author{
Timothy Olanrewaju*, Rolayo Emmaunel, Olusola Olaleye
}

Nigerian Institute for Trypanosomiasis Research (NITR), P.M.B 2077, No. 1 Surami Road, Ungwan Rimi, Kaduna, Nigeria.

*Corresponding Author: E-mail: timothyseye@ gmail.com, Telephone: +2347067961445, +2348152037884

Background: The prospect of immunization against the African trypanosomiasis appears remote due to it phenomenal antigenic variation. It is therefore necessary to search for new and more potent anti-trypanosomal compounds of natural origin to complement the existing synthetic anti-trypanosomal drugs that are gradually becoming less potent against the pathogenic trypanosomes. This study aimed at evaluating the prophylactic activity of aqueous and methanolic extract of Andrographis paniculata in Trypanosoma brucei brucei infected mice.

Methods: Thirty six (36) male Swiss mice of average weight 22g-26g were group into six (6) groups of six (6) animals each. Group (A-D) were orally administered $5000 \mathrm{mg} / \mathrm{Kg}$ of methanolic leaf, methanolic stem, aqueous leaf and aqueous stem extract of $A$. paniculata respectively while group $\mathrm{E}$ and $\mathrm{F}$ were the untreated and uninfected control group respectively. Animals were inoculated with $10^{2}$ trypanosomes intraperitoneally after 10 days of extracts administration. The parasite growth, rectal temperature, weight, PCV and some haematological indices were monitored.

Results: High parasitic replication was observed in untreated group with $100 \%$ mortality on $10^{\text {th }}$ day post infection. Some treated mice survived beyond 17 days post infection with no appearance of parasite $(\mathrm{A}=50 \%, \mathrm{~B}=50 \%, \mathrm{C}=67 \%$ and $\mathrm{D}=33 \%)$. The rectal temperature showed no significant difference $(\mathrm{P}<0.05)$ in all treated group when compared with control on $17^{\text {th }}$ day post infection. Mean weight of group A and D showed no significant difference $(\mathrm{P}<0.05)$ compared to control group while group $\mathrm{B}, \mathrm{C}$ and untreated showed significant difference. Treated mice maintained stable PCV but there was reduction in untreated group. Untreated group revealed increase in lymphocyte and monocyte count compared with control group. No significant difference in monocyte and neutrophil count in the treated groups when compared with control group $(\mathrm{P}<0.05)$. 
WANNPRES 2014 ABSTRACTS Afr J Tradit Complement Altern Med. (2015) 12(S):1-44 http://dx.doi.org/10.4314/ajtcam.v12i5.1S

Conclusion: A. paniculata leaf and stem contain bioactive components that exhibited trypanocidal activity. The plant has compounds which can be isolated for the development of cheap, safe and effective drugs for the treatment and management of African trypanosomiasis.

Key words: Andrographis paniculata; Typanosoma brucei brucei; parasitaemia; trypanocidal activity; prophylactic.

\title{
OP-11
}

\section{STUDIES OF THE ANTITRYPANOSOMAL AND TOXICOLOGICAL PROPERTIES OF ANOGEISSUS LEIOCARPUS (DC.) GUILL.\& PERR. (COMBRETACEAE) AND VITELLARIA PARADOXA C. F. GAERTN (SAPOTACEAE) IN MICE}

\author{
${ }^{1}$ Akintunde Awokunlehin, ${ }^{1}$ Christianah A. Elusiyan, ${ }^{2}$ Ronald A. Bejide, ${ }^{3}$ Efere M. Obuotor and ${ }^{1 *}$ Clement O. Adewunmi \\ ${ }^{I}$ Drug Research and Production Unit, Faculty of Pharmacy, \\ ${ }^{2}$ Department of Morbid Anatomy and Forensic Medicine, Faculty of Clinical Sciences, \\ ${ }^{3}$ Department of Biochemistry, Faculty of Science, Obafemi Awolowo University (OAU), Ile-Ife.
}

*Corresponding author:Email:cadewumi@yahoo.com;

Background: The economic and devastating effects of African animal trypanosomosis (AAT) have increased dramatically in recent years especially in Sub-Saharan Africa. Currently available treatment options are not only insufficient but most importantly, the available trypanocidal drugs are toxic. The study investigates the antitrypanosomal activities and the toxicological profile of the stem bark extract of Anogeissus leiocarpus and Vitelleria paradoxa used by ethno-veterinary medical practitioners in the North-Eastern and Central Nigeria.

Methods: Anti-trypanosomal properties of ethanolic extracts and fractions therefrom were investigated in-vivo using mice (19g - 26g) while the toxicological effects were determined in rats $(140 \mathrm{~g}-165 \mathrm{~g})$. Mice were inoculated via the intraperitoneal route with $10^{4}$ parasites in $0.2 \mathrm{ml}$ of the inoculums in eight groups and grouped ( $\mathrm{n}=5 / \mathrm{group}$ ) and in doses of $0.0,62.5,125.0,250.0 \mathrm{mg} / \mathrm{kg}$ for $A$. leiocarpus and 50.0, 100.0 and $200 \mathrm{mg} / \mathrm{kg}$ for V. paradoxa ethanolic extracts. $3.5 \mathrm{mg} / \mathrm{kg}$ diminazine aceturate was used as the standard drug. The antitrypanosomal, acute, sub-chronic, biochemical and histopathological profiles were determined following standard test protocols.

Results:V. paradoxa stem bark extract showed neither trypanocidal nor trypanostatic activities while A. leiocarpus stem bark extract was found to be trypanostatic at 62.5 and $125 \mathrm{mg} / \mathrm{kg}$ body weight. However, the partitioned aqueous fraction of A. leiocarpus was found to demonstrate comparable anti-trypanocidal effect as Diminal (standard agent). The histological appearance of the four organs (heart, kidney, lung and liver) obtained from treated animals shows no remarkable distortion (ulceration) and damaging effects at the tested doses $(85,170,340$ and $680 \mathrm{mg} / \mathrm{kg}$ ) when compared with the control group, in which also no evidence of tissue damage could be found.

Conclusion:A. leiocarpus possessed weak antitrypanosomal activity. The study established the relative safety of A. leiocarpus stem bark extract in rats. 


\title{
WANNPRES 2014 ABSTRACTS Afr J Tradit Complement Altern Med. (2015) 12(S):1-44 http://dx.doi.org/10.4314/ajtcam.v12i5.1S
}

\section{OP-12}

\author{
A REPORT ON THE TOXICITY POTENTIAL OF UVARIA CHAMAE N-HEXANE FRACTION \\ ${ }^{* 1}$ Bamimore V. O., ${ }^{1}$ Elusiyan C. A., ${ }^{2}$ Obuotor E. M., ${ }^{3}$ Adeyemi D. O., ${ }^{1}$ Adewunmi C. O., \\ ${ }^{1}$ Drug Research and Production Unit, Faculty of Pharmacy Obafemi Awolowo University, Ile-Ife, Nigeria. \\ ${ }^{2}$ Department of Biochemistry Faculty of Science Obafemi Awolowo University, Ile-Ife, Nigeria. \\ ${ }^{3}$ Department of Anatomy and Cell Biology, Obafemi Awolowo University, Il-Ife, Nigeria.
}

*Corresponding author: Email: torilola17@yahoo.com. Telephone, Tel: +2347068679911.

Background: Uvaria chamae (Annonaceae) has showed a considerable activity against Trypanosomal brucei parasite in-vivo by increasing the survival time of infected mice, a useful anti-trypanosomal substance must have a defined toxicity profile which is why this study is necessary.

Materials and Methods: Both acute and sub-chronic toxicity studies were carried out on the $n$-hexane fraction of Uvaria chamae leaves. Acute toxicity was carried out using the Lorkes (1983) method. Serum and liver homogenate were analysed for biochemical parameters such as aspartate aminotransferase (AST), alanine aminotransferase (ALT), total cholesterol (TCHOL), and triglyceride (TG) for the sub-chronic toxicity study. Histopathological procedure was also carried out on selected tissues.

Results: The acute toxicity was given as $>5000 \mathrm{mg} / \mathrm{kg}$, however observations from the sub-chronic administration showed a significant difference from the control at $(\mathrm{p}<0.05)$ test of significance especially for AST and ALT parameters in a dose dependent manner in the liver and serum homogenates respectively, similarly histopathological studies showed several morphological changes different from the control group and typical to those reported for deranged tissues.

Conclusion: The results from this study have showed that even though the $n$-hexane fraction of Uvaria chamae showed no acute toxicity at high doses, a prolonged dosage is NOT recommended.

\section{OP-13}

\section{AQUEOUS EXTRACT OF ANOGEISSUS LEIOCARPUS (AEAL) INDUCED ENDOTHELIUM-DEPENDENT VASODILATATION EFFECTS ON PORCINE CORONARY ARTERY RINGS.}

\author{
L. Belemnaba ${ }^{a, b}$, S. Ouédraogo ${ }^{a}$, C. Auger ${ }^{b}$, T. Chataigneau ${ }^{\text {, I. P. Guissou }}{ }^{a}$, C. Lugnier ${ }^{b}$, V. B. Schini-Kerth ${ }^{\text {b B. Bucher }}{ }^{\text {b }}$ \\ ${ }^{1}$ Institut de Recherche en Sciences de la Santé (IRSS/CNRST), Burkina Faso \\ . ${ }^{2}$ Laboratory of Biophotonics and Pharmacology, UMR 7213, University of Strasbourg, Faculty of Pharmacy, illkirch, France
}

Background: Anogeissus leiocarpus is a tree of the Sahel to forest of Africa and and reported to possess antimicrobial, antifungal, trypanocidal and antihypertensive properties. In Burkina Faso, Anogeissus leiocarpus is traditionaly used to treat several diseases including hypertension. In this study, experiments were undertaken to evaluate whether AEAL extracted from Anogeissus leiocarpus bark induces a vasodilator effect on porcine coronary artery rings, and if so, to elucidate the underlying mechanism.

Material and Method:Porcine coronary artery rings were suspended in organ chambers for the measurement of changes in isometric tension.

Results: $A E A L$ induced endothelium-dependent vasodilation effect was abolished in endothelium-denuded porcine coronary artery rings. This relaxation effect was inhibited in the presence of $\mathrm{N}^{\omega}$-nitro-L-arginine (L-NA, eNOS inhibitor), or the combination of L-NA plus charybdotoxin (CTX) plus apamin (APA) (EDHF-mediated inhibitors) and in the presence of $1 \mathrm{H}-$ $[1,2,4]$ oxadiazolo[4,3a]quinoxalin-1-on. 


\title{
WANNPRES 2014 ABSTRACTS Afr J Tradit Complement Altern Med. (2015) 12(S):1-44 http://dx.doi.org/10.4314/ajtcam.v12i5.1S
}

This relaxation effect to AEAL were abolished in the presence of the superoxide dismutase mimetic Mn(III)tetrakis(1-methyl-4pyridyl) porphyrin, whereas, native catalase or native superoxide dismutase or the cell permeable catalase had either no or only small effect on the $A E A L$ endothelium-dependent vasorelaxation.

The endothelium-dependent relaxation to $A E A L$ were slightly but significantly reduced by a combination of CTX plus APA, in the presence of 2-(4-morpholinyl)-8-phenyl-4H-1-benzopyran-4-one and in the presence of 4-amino-5-(4-chlorophenyl)-7-(tbutyl)pyrazolo[3,4-d]pyrimidine). Moreover, treatment of endothelial cells with $A E A L$ is associated with an intracellular generation of ROS.

Conclusion:Taken together, $A E A L$ induces endothelium-dependent relaxations on porcine coronary arteries, which involve a NOmediated component but also, partially, an EDHF-mediated component.

Key words: Anogeissus leiocarpus; Vasorelaxation; Hypertension; Nitric oxide; EDHF.

\section{OP-14}

\section{INHIBITION OF KEY ENZYMES LINKED TO TYPE-2 DIABETES MELLITUS AND ANTI-OXIDATIVE EFFECT OF VARIOUS SOLVENT FRACTIONS FROM FRUIT ETHANOLIC EXTRACT OF AFRAMOMUM MELEGUETAK. SCHUM. IN VITRO}

\author{
Aminu Mohammed, ${ }^{1,2}$ and Md. Shahidul Islam ${ }^{1}$ \\ ${ }^{1}$ Discipline of Biochemistry, School of Life Sciences, University of KwaZulu-Natal, (Westville Campus), Durban, 4000, South \\ Africa \\ ${ }^{2}$ Department of Biochemistry, Ahmadu Bello University, Zaria-Nigeria
}

Correspondence author: E-mail: alamindagash27@gmail.com or 212562498@stu.ukzn.ac.za

Tel: +2348061333502 or +27840134839

Background: Various parts of Aframomum melegueta K. Schum. (Zingiberaceae) are used locally in treatment of diabetes mellitus in different parts of Africa and Asia. In our previous study, fruit ethanolic extract exhibited higher anti-oxidative and anti-diabetic effects compared to other solvent extracts from different parts of A. melegueta. Thus, the present study investigated and compared the antioxidative and inhibitory effects on key enzymes linked to type-2 diabetes mellitus of various fractions from fruit ethanolic extract of A. meleguetain vitro. Additionally, possible active compounds present on the most active fraction were investigated by Gas Chromatography-Mass Spectrometry (GC-MS) analysis.

Methods: Fruit ethanolic extract was fractionated using solvents of increasing polarity and investigated for 1,1-diphenyl-2-picrylhydrazyl (DPPH) radical scavenging activity, inhibitions of haemoglobin glycosylation, $\alpha$-amylase and $\alpha$-glucosidase activities as markers of in vitro anti-diabetic effects. Possible bioactive compounds were analyzed using Gas Chromatography-Mass Spectrometry (GC-MS) analysis.

Results:The results showed that acetone fraction exhibited significantly $(\mathrm{p}<0.05)$ higher total polyphenols and flavonoids contents with potent DPPH radical scavenging activity $\left(\mathrm{IC}_{50}\right.$ value: $69.88 \pm 3.34 \mu \mathrm{g} / \mathrm{ml}$ ) compared to other solvent fractions which was comparable with the standards ascorbic acid ( $\mathrm{IC}_{50}$ value: $\left.25.34 \pm 6.19 \mu \mathrm{g} / \mathrm{ml}\right)$ and gallic acid $\left(\mathrm{IC}_{50}\right.$ value: $\left.20.01 \pm 4.42 \mu \mathrm{g} / \mathrm{ml}\right) \mathrm{used}$. Similar result was obtained for inhibition of hemoglobin glycosylation as indicated by lower $\mathrm{IC}_{50}$ value $(111.33 \pm 6.46 \mu \mathrm{g} / \mathrm{ml})$ compared to gallic acid $(199.09 \pm 2.85 \mu \mathrm{g} / \mathrm{ml})$. Furthermore, acetone fraction had significantly $(\mathrm{p}<0.05)$ higher $\alpha$-amylase and $\alpha$ glucosidase inhibitory effects compared to other solvent fractions as well as acarbose in concentration dependent manner. The $\mathrm{IC}_{50}$ values obtained were acetone ( $\alpha$-amylase: $68.69 \pm 6.05 \mu \mathrm{g} / \mathrm{ml} ; \alpha$-glucosidase: $40.44 \pm 5.77 \mu \mathrm{g} / \mathrm{ml})$ compared to acarbose $(\alpha$-amylase: $4904 \pm 784.85 \mu \mathrm{g} / \mathrm{ml} ; \alpha$-glucosidase: $335.34 \pm 8.86 \mu \mathrm{g} / \mathrm{ml})$. The GC-MS analysis of acetone fraction revealed the presence of $p$-cresol, paradol, zingerone and phthalic acid mono-(2-ethylhexyl) ester as the major compounds present. 


\title{
WANNPRES 2014 ABSTRACTS Afr J Tradit Complement Altern Med. (2015) 12(S):1-44 http://dx.doi.org/10.4314/ajtcam.v12i5.1S
}

Conclusion:Acetone fraction exhibited strong anti-oxidative and inhibitory effects of key enzymes linked to type-2 diabetes mellitus compared to other solvent fractions in vitro and thus require further work to fully validate these effects in-vivo.

Key words: Type-2 diabetes mellitus, Aframomum melegueta, DPPH, hemoglobin, $\alpha$-amylase, $\alpha$-glucosidase

\section{OP-15}

\section{FORMULATION OF FICUS EXASPERATA LEAF EXTRACT INTO TABLET DOSAGE FORM.}

\author{
Tolulope Ajala ${ }^{1}$, Ayobami Olusola ${ }^{2}$, Oluwatoyin Odeku ${ }^{1}$ \\ ${ }^{I}$ Department of Pharmaceutics and Industrial Pharmacy, Faculty of Pharmacy, University of Ibadan, Ibadan \\ ${ }^{2}$ Department of Pharmaceutics and Pharmaceutical Technology, Faculty of Pharmacy Olabisi Onabanjo University, Ago-Iwoye.
}

Corresponding author: Email: tolulola1721@gmail.com, Tel: +2348022171674

Background: Ficus exasperata (Vahl) from the family Moraceae is an herb of ethnobotanical importance with antihypertensive, antidiabetic and antimicrobial properties. Most studies have concentrated on the phytochemistry and pharmacological activities of the plant, but there is a need to formulate this valuable herb into tablet dosage form to offer standardization, accurate dosing and acceptable presentation to the users.

Methods: The ethanol extract of Ficus exasperata leaves was obtained by maceration and assessed for antimicrobial activity on six bacteria and four fungi using agar cup diffusion method. The extract was formulated into tablets by direct compression method with Avicel, Emcompress and Directly Compressible Lactose (DCL) as excipients using varying drug-excipient ratio (DEXR). The flow properties of the powder mix were determined using compressibility index, Hausner's ratio, angle of repose and density measurements. The mechanical properties of the tablets were assessed using crushing strength (CS), friability (F) and the crushing strength:friability ratio (CSFR) and release properties with disintegration time (DT), disintegration efficiency ratio (DER) and dissolution time.

Results: The results showed that the extract had concentration-dependent antibacterial and antifungal activity. The flow properties of the powder mixes improved as DEXR decreased. Tablet evaluation revealed that CS and CSFR increased while F decreased with increase in compression force and DEXR. The grading for CS and CSFR of tablets containing different excipients was Avicel > DCL $>$ Emcompress but the trend was vice-versa for friability. For DT, the ranking was also Avicel $>$ DCL $>$ Emcompress but changed in dissolution times to Avicel > Emcompress > DCL. There were significant differences $(p<0.05)$ in the flow properties of the powder mix, mechanical and release properties of the tablets.

Conclusion: The tablets of Ficus exasperata leaf extract have acceptable mechanical and release parameters which varied with excipient type, concentration and compression pressure. In the formulation of the tablets, there is a need for careful selection of the formulation variables to obtain tablets with optimum parameters.

Key words:Ficus exasperataleaf extract, tablets, excipients, direct compression, mechanical and release properties. 


\title{
WANNPRES 2014 ABSTRACTS Afr J Tradit Complement Altern Med. (2015) 12(S):1-44 http://dx.doi.org/10.4314/ajtcam.v12i5.1S
}

\section{OP-16}

\section{SUBCHRONIC TOXICITY OF TDLM ANTIMALARIA HERBAL FORMULATION}

\author{
Oyedele Titilayo Oyebola, Salihu Timothy, Borgu Ewoma Lugard and Orgah Emmanuel Adiku
}

Nigeria Natural Medicine Development Agency (FMST), 9, Kofo Abayomi Street, Victoria Island Lagos, Nigeria

*Corresponding author:oyedebola@yahoo.com Telephone: +2348067780439

Background: Because of reported adverse drug reactions associated with herbal medicines, there is need to conduct pre-clinical toxicological studies on all herbal remedies intended for human use. TDLM is a herbal antimalaria formulation comprising Tithonia diversifolia and Lippia multiflora as components. The aim of the present study was to evaluate the safety of Tithonia diversifolia and Lippia multiflora aqueous leaf combination through sub- chronic toxicity study.

Method: The herbal antimalaria formulation was administered to Swiss albino mice (18-20 g weight) at doses of 250, 500 and 1000 $\mathrm{mg} / \mathrm{kg}$ body weight for 28 days and the animals wereobserved.

Results: At extract doses of $250 \mathrm{mg} / \mathrm{kg}, 500 \mathrm{mg} / \mathrm{kg}$ and $1000 \mathrm{mg} / \mathrm{kg}$, there was an increase in body weight from days $0-7$, by days 14 $\& 21$, the group treated with $250 \mathrm{mg} / \mathrm{kg}$ increased in body weight, while groups treated with 500 and $1000 \mathrm{mg} / \mathrm{kg}$ of extract dropped in weight. By day 28, all the treated groups experienced a decrease in weight except the group treated with $500 \mathrm{mg} / \mathrm{kg}$. The observed overall increase in vital organs was statistically insignificant in TDLM treated groups compared with the control. Selected doses of $250,500,1000 \mathrm{mg} / \mathrm{kg}$ of the combined extract had little or no effect on the PCV of experimental animals, however, animals treated with $1000 \mathrm{mg} / \mathrm{kg}$ showed a reduced PCV on day 28 . There was a slight dose dependant increased in activities of ALT, AST, and ALP which was not significant in the TDLM treated groups compared with the control.

\section{Conclusion}

The elevation in liver function parameters as found in this work and the overall increased in vital organs in the TDLM treated groups compared to the control was not significant to indicate toxicity.

Key words: Subchronic, Toxicity, Antimalaria, Therapy

\section{OP-17}

\section{THE PROPHYLACTIC POTENTIAL OF NIBIMA ${ }^{\circledR}$, A GHANAIAN HERBAL ANTIMALARIAL PRODUCT}

\author{
K.P. Thomford ${ }^{1 *}$, D.A Edoh ${ }^{1}$, A.K. Thomford ${ }^{2}$, A.A. Appiah ${ }^{1}$ \\ ${ }^{1}$ Centre for Plant Medicine Research, P.O.Box 73, Mampong-Akwapim, Ghana \\ . $\quad{ }^{2}$ Department of Biomedical and Forensic Sciences, University of Cape Coast, Ghana \\ *Email:kpthomford@hotmail.com
}

Background: Cryptolepis sanguinolenta (Lindl.) is a plant well known for its antimalarial properties. A decoction prepared from the aqueous root extract of the plant has been used at the Centre for Plant Medicine Research (CPMR), Mampong-Akwapem as an antipyretic and antimalarial for several years. However, there are concerns about associated recrudescence post treatment with the product sold under the trade name Nibima ${ }^{\circledR}$.

Objective: The study seeks to establish the secondary benefit of using the product as an antimalarial. This benefit was classified as the delay in recrudescence: absence of parasitaemia and cardinal signs of malaria such as fever and anaemia, over a 45-day period. 


\title{
WANNPRES 2014 ABSTRACTS Afr J Tradit Complement Altern Med. (2015) 12(S):1-44 http://dx.doi.org/10.4314/ajtcam.v12i5.1S
}

Methods: Ten (10) participants were involved in the study, with a mean age of $32.70( \pm 17.45)$ comprising 7 males and 3 females. Patients clinically diagnosed with uncomplicated malaria: defined as parasitaemia of $>1000 / \mu 1$ on thick blood film together with clinical signs and symptoms were followed up for 45 days. Participants received a treatment of the herbal medicine Nibima ${ }^{\circledR}$ at varied doses of $60-100 \mathrm{~mL}$ three times daily for 7 days after which the thick blood film for parasitaemia was repeated. Each participant was then followed up for recrudescence with thick blood film and full blood count (FBC) examinations on days 14,28 and 45 .

Results: Parasitaemia for all the participants were in the range of $10^{3}-10^{4} / \mu \mathrm{l}$, mean WBC $(9.10 \pm 0.20), \mathrm{Hb}(10.08 \pm 1.29 \mathrm{~g} / \mathrm{dl})$. The repeat of the thick blood film on Day 7 showed a total clearance of all malaria parasites, WBC (9.27 \pm 2.16$)$ and $\mathrm{Hb}(11.27 \pm 0.27$ $\mathrm{g} / \mathrm{dl}$ ). Monitoring during the follow up period (Day 14, 28 and 42) also indicated the absence of parasitaemia. Mean WBC and Hb was $(4.64 \pm 0.24)$ and $(11.49 \pm 1.44 \mathrm{~g} / \mathrm{dl})$ respectively on day 42.

Conclusion: The prevention of possible malaria recrudescence by the herbal product Nibima ${ }^{\circledR}$ means that apart from the product being used primarily for the treatment of malaria, it may also hold some prophylactic potential that may need further investigation.

Keywords: Clinical studies, Cryptolepis sanguinolenta, Herbal medicines, Malaria, Nibima ${ }^{\circledR}$,

OP-18

\section{NIGELLA SATIVA CONCOCTION AND HAART POTENTIALLY CURED HIV INFECTION}

\section{A. A Onifade}

Immunology unit, Chemical Pathology department, College of Medicine, University of Ibadan, Nigeria

Background: The combination of HAART and Nigella sativa concoction in HIV infection would be a great concern to health care provider especially when the latter efficacy had not been widely accepted as anti-retroviral agent.

Method: This study highlighted a 34 year old woman that presented with history of un-explained fever, weight loss and diarrhoea. HIV screening (EIA) and Western blot confirmed HIV infection with pre-treatment CD4 count of 280 cells/ $\mu \mathrm{L}$ and viral (HIV-RNA) load of 25,000 copies per $\mathrm{ml}$. She was commenced on HAART (200mg of nevirapine, 150mg of lamivudine and 300mg of zidovudine) daily and $10 \mathrm{ml}$ twice daily of Nigella sativa herbal concoction. The patient was monitored daily for effectiveness and possible adverse drug reaction.

Results: Fever and diarrhoea disappeared on $10^{\text {th }}$ and $13^{\text {th }}$ day respectively on combination of HAART and Nigella sativa concoction. The CD4 count was $250,300,450$ and 500 cells $/ \mu \mathrm{L}$ at $3^{\text {rd }}, 6^{\text {th }}, 9^{\text {th }}$ and $12^{\text {th }}$ month respectively on therapy. The viral (HIV-RNA) load was undetectable and several repeats of HIV antibody tests (EIA) were negative on $13^{\text {th }}$ month on combination therapy.

Conclusion: It was concluded that combination therapy of HAART and Nigella sativa concoction potentially cured HIV infection (complete recovery and sero-reversion) in this patient and the study is on going to determine the effect of discontinuation of the therapy.

Key words: HAART, Nigella sativa, HIV infection, combination therapy

\section{OP-19}

\section{ANTI-HIV-1 REPLICATION PROPERTIES OF A HERBAL PREPARATION (PHEKO)}

\author{
Lufuno Mavhandu' ${ }^{1}$, Daphney Matume, Mamello Sekhoacha², Pascal Bessong ${ }^{1}$ \\ ${ }^{1}$ HIV/AIDS and Global Health Research Programme, Department of Microbiology, University of Venda, Thohoyandou 0950,
} South Africa. 


\title{
WANNPRES 2014 ABSTRACTS Afr J Tradit Complement Altern Med. (2015) 12(S):1-44 http://dx.doi.org/10.4314/ajtcam.v12i5.1S
}

\author{
${ }^{2}$ Indigenous Knowledge Systems Research Laboratory, Medical Research Council, Cape Town, South Africa.
}

Corresponding author: Email: bessong@ univen.ac.za Tel: +27 159628301

Background: Infection with human immunodeficiency virus (HIV) is of global public health concern. Highly active antiretroviral therapy (HAART) significantly reduces morbidity and mortality due to AIDS, the outcome of HIV infection. However, due to the limitations of HAART, alternative forms of treatment, such as herbal therapies, are common in developing communities. The current study investigated the anti-HIV effects of Pheko (a herbal preparation) for inhibitory effects against two essential HIV enzymes.

Methods: Several extract types of Pheko were assayed for inhibitory effects against HIV-1 reverse transcriptase (RT) and integrase (IN) in cell-free assays. Additionally, the methanol extract was studied for anti-replicative properties against wild and resistant pseudoviruses of HIV-1 subtypes B and C. Viruses used included wild type and resistant mutants of NL4-3 (HIV-1 subtype B) and wild type Indie C (HIV-1 subtype C).The cytotoxicity of the extracts against the human cell lines (U87.CD4.CCR5 and Vero T35) was evaluated with the Lactate dehydrogenase (LDH) assay for cell death and MTT (3-[4, 5-Dimethylthiazol-2-yl]-2.5diphenyltetrazolium bromide) assay for cell viability.

Results: The water extract of Pheko inhibited IN with an $\mathrm{IC}_{50}$ of $125 \mu \mathrm{g} / \mathrm{ml}$. Dichloromethane extract was the most inhibitory to RT with an $\mathrm{IC}_{50}$ of $3 \mu \mathrm{g} / \mathrm{ml}$. The methanol extract also showed excellent HIV-1 RT inhibition $\left(\mathrm{IC}_{50}\right.$ of $\left.20 \mu \mathrm{g} / \mathrm{ml}\right)$. Transformation competent cells were successfully generated and successfully used to prepare plasmids for HIV-1 subtype C-based pseudoviral packaging. In the pseudovirus assays, the methanol extract inhibited RT activity of HIV-1 subtype C virus (Indie C) with an IC 50 of 25 $\mu \mathrm{g} / \mathrm{ml}$. Of interest was the strong inhibition of the NRTI and NNRTI resistant strains of HIV-1 subtype B (NL4-3) by the methanol extract with $\mathrm{IC}_{50}$ values of $35 \mu \mathrm{g} / \mathrm{ml}$ and $21 \mu \mathrm{g} / \mathrm{ml}$ respectively. Low selective indices were observed on the background of U87.CD4.CCR5 cell line as target for the pseudoviruses (range 0.01-0.023).

Conclusion: This preliminary data shows that the methanol extract of Pheko can potentially inhibit HIV-1 Subtypes B and C viruses resistant to nucleoside RTI and non-nucleoside RTI. Future work will focus on the dichloromethane and methanol extracts of Pheko.

\section{POSTER PRESENTATIONS}

P-01

\section{MANAGEMENT OF DIARRHOEA IN LIVESTOCK WITH MEDICINAL PLANTS}

\author{
Salihu ${ }^{*}$ Timothy, Mbaoji Camillus. ${ }^{1}$, Chibukem Anoruo-dibia ${ }^{1}$, Etatuvie $^{1}$ Samuel. O, \\ Tamuno-Ibuomi F. Okujagu ${ }^{1}$ and Arowolo Reuben.O. ${ }^{2}$ \\ ${ }^{I}$ Nigeria Natural Medicine Development Agency(FMST) 9, Kofo Abayomi Street, Victoria Island Lagos, Nigeria \\ ${ }^{2}$ Department of Veterinary Physiology and Pharmacology, Faculty of Veterinary Medicine, University of Ibadan
}

*Corresponding author: salitim@yahoo.com Telephone: +2348094841537

Background: Diarrhoea, a common clinical sign observed in infectious and non-infectious diseases has been found to be the main cause of mortalities in livestock diseases, if not well managed. The use of herbal drugs in the treatment of gastrointestinal disorders including diarrhoea is a common practice among Fulani herdsmen in Nigeria and is usually preferred because it is a cheaper alternative.

Recent efforts on ethnopharmacology revealed several of these medicinal plants as potential antidiarrhoeal. A great number of plant derived therapeutic agents have been discovered following leads provided by indigenous knowledge. This study was designed to 25 


\title{
WANNPRES 2014 ABSTRACTS Afr J Tradit Complement Altern Med. (2015) 12(S):1-44 http://dx.doi.org/10.4314/ajtcam.v12i5.1S
}

document ethnoveterinary practices used in the treatment of diarrhoea among Fulani herdsmen in Taraba State, Nigeria. Information provided will enable further study on the efficacy of the medicinal plants identified.

Method: Eight Local government areas (LGAs) of Taraba State, Nigeria were selected for the survey. The local government areas surveyed include; Donga, Gashaka, Gassol, Ibi, Kurmi, Sardauna, Takum and Wukari, Sixty four herdsmen with good knowledge of livestock diseases and ethnoveterinary practice were interviewed.

Result: 25 plants species belonging to 14 plant families were documented as remedies for the management of diarrhoea in livestock by the Fulani herdsmen interviewed. Khaya senegalensis was the most frequently used plant.

Conclusion: Fulani herdsmen are vast in ethnoveterinary knowledge. Some of the plants documented as used by them have demonstrated antidiarrhoeal properties from preliminary studies, while some of them are yet to be investigated. The efficacy and toxicity of these plants should be further investigated.

Key words: Diarrhoea, antidiarrhoeal, ethnopharmacology, ethnoveterinary, livestock

P-02

ANTIMICROBIAL RESISTANCE EVALUATION OF ORGANISMS ISOLATED FROM LIQUID HERBAL PRODUCTS MANUFACTURED AND MARKETED IN SOUTH EASTERN NIGERIA.

\author{
Ujam Nonye1, Oli Angus ${ }^{1}$, Ikegbunam Moses ${ }^{1}$, Adikwu Michael ${ }^{2}$ and Esimone Charles ${ }^{1}$ \\ ${ }^{I}$ Department of Pharmaceutical Microbiology and Biotechnology, Faculty of Pharmaceutical Sciences,NnamdiAzikiweUniversity, \\ Agulu Campus, Nigeria. \\ ${ }^{2}$ Department of Pharmaceutics, Faculty of Pharmaceutical Sciences, University of Nigeria, Nsukka,Nigeria.
}

*Corresponding author:nonyetreasure@yahoo.com Telephone: +2348064667066

Background: Over $80 \%$ of the world population currently depends on herbal medicine products for healthy living. Most of these products have been reported to be contaminated and may serve as potential sources of transmission of pathogenic spoilage organisms from product to consumers. Presence of antibiotic resistant microbial isolates in Herbal Medicine Products (HMPs) could lead to transfer of antibiotic resistance traits to sensitive oral microflora of consumers. The susceptibility and resistance pattern of bacteria and fungi isolates obtained from liquid herbal anti-infectives manufactured and marketed in South-East Nigeria to conventional antibiotics were determined.

Methods: Isolation of contaminating microorganisms was carried out using pour plate technique and they were characterized by the morphological appearance of their colonies, microscopy and confirmatory biochemical tests. A total of forty-nine (49) bacteria and forty (40) fungi isolated from the herbal products were examined for susceptibility to conventional antibiotics using the disc diffusion method. The bacterial isolates were tested against ciprofloxacin, ofloxacin, amoxicillin-clavulanic acid, gentamicin, cefotaxime, ceftazidime, ceftriaxone, sulphamethoxazole, tetracycline and ampicillin while fungi isolates were tested against five common antifungal agents; griseofulvin, nystatin, ketoconazole, fluconazole and clotrimazole. The Multiple Antibiotic Resistance Index (MARI) of the isolated bacteria was calculated using the formula, MARI $=\mathrm{a} / \mathrm{b}$.

Results: The antimicrobial susceptibility-resistance profile of the bacteria isolates revealed that most of the bacteria showed $>50 \%$ susceptibility to ciprofloxacin, ofloxacin, gentamicin, and ceftriaxone. However, majority of the isolates demonstrated $100 \%$ resistance to common antibiotics like Ampicillin, amoxycillin-clavulanic acid, trimethoprim-sulphamethoxazole, and $\leq 50 \%$ resistance to tetracycline, cephalosporins, ceftazidime and cefotazime. Calculation of MARI revealed that most of the isolates were resistance to more than fifty percent $(50 \%)$ of antibiotics used. The fungal isolates showed $<40 \%$ susceptibility to nystatin, ketoconazole and clotrimazole, $\geq 50 \%$ resistance to fluconazole and $100 \%$ resistance against griseofulvin. 
WANNPRES 2014 ABSTRACTS Afr J Tradit Complement Altern Med. (2015) 12(S):1-44 http://dx.doi.org/10.4314/ajtcam.v12i5.1S

Conclusion: The results of this study revealed that the herbal medications can serve as a trail of spread of antimicrobial resistance genes.

\title{
$\mathbf{P - 0 3}$
}

\section{ANTIMICROBIAL ACTIVITIES OF SOME HERBAL ANTI-INFECTIVES MANUFACTURED AND MARKETED} IN SOUTH-EAST NIGERIA.

\author{
Ujam Nonye ${ }^{1}$, Oli Angus ${ }^{1}$, Ikegbunam Moses ${ }^{1}$, Uzodimma Samuel ${ }^{2}$, Anagu Linda1, Adikwu Michael3and Esimone Charles ${ }^{1}$ \\ ${ }^{I}$ Department of Pharmaceutical Microbiology and Biotechnology, Faculty of Pharmaceutical Sciences,NnamdiAzikiweUniversity, \\ Agulu Campus, Nigeria. \\ ${ }^{2}$.Department of Clinical Pharmacy and Pharmacy Management, Faculty of Pharmaceutical Sciences,NnamdiAzikiweUniversity, \\ Agulu Campus, Nigeria. \\ ${ }^{3}$ Department of Pharmaceutics, Faculty of Pharmaceutical Sciences, University of Nigeria, Nsukka,Nigeria.
}

*Corresponding author:nonyetreasure@yahoo.com Telephone: +2348064667066

Background: In Nigeria, there appears to be an overwhelming increase in public awareness and usage of Herbal Medicinal Products (HMPs) in the treatment and/or prevention of diseases. Traditional herbalists in Nigeria use various herbal preparations to treat different types of ailments; diarrhea, urinary tract infections, typhoid fever and skin diseases. World Health Organisation (WHO) supported the integration of HMPs into the primary health care system of developing countries. However, safety issues related to these products are often ignored by the herbalist whose methods of mixing herbal preparations for the public are usually unhygienic with the attendant microbiological hazards. The anti-microbial activities of twenty liquid herbal anti-infectives manufactured and marketed in South-Eastern Nigeria were evaluated and the extent of their microbial contamination determined.

Methods:Antimicrobial activities of the herbal anti-infectives were evaluated using agar-well-diffusion method. The samples that showed substantial antibacterial activity against the test organisms were further subjected to cell-killing-rate test. Maximum inhibitory dilutions of the active samples were determined using macrobroth dilution method and their activity against Multidrug Resistance Staphylococcus aureus (MRSA) and Extended Spectrum $\beta$-Lactamase (ESBL) producing organisms were evaluated.

Results:Eight (40\%) of the products showed some antibacterial activity and none have antifungal activity against the test fungi though $6(30 \%)$ claimed to have from their labels. Kill kinetic experiment showed that they have bactericidal activity against the test bacteria. Comparison of the antibacterial activity of the products and conventional antibiotics showed that there was no significant difference among the microorganism in their susceptibilities to the antibiotics $(\mathrm{F}=0.498, \mathrm{P}=0.686)$ and herbal anti-infectives $(\mathrm{F}=0.477, \mathrm{P}=$ 0.700). The herbal anti-infectives were all contaminated by potentially pathogenic microorganisms.

Conclusion:Constant monitoring and quality control of herbal medicinal products produced, advertised, sold and consumed in Nigeria is necessary. The government should, through the right agencies, take adequate control measures to set specific standards for quality for herbal medicines.

\section{P-04}

ETUDE DE L'EFFICACITÉ, DE L'INNOCUITÉ ET DE LA QUALITÉ D'UNE PRÉPARATION À BASE DE CASSIA OCCIDENTALIS (FABACEAE) ISSUE DE LA MÉDECINE TRADITIONNELLE 


\title{
WANNPRES 2014 ABSTRACTS Afr J Tradit Complement Altern Med. (2015) 12(S):1-44 http://dx.doi.org/10.4314/ajtcam.v12i5.1S
}

\author{
G. Kouakou-Siransy*, G. Irié-Nguessan, KE. Effo, BJ. Kablan \\ Institut d'attache des auteurs : UFR Sciences Pharmaceutiques et Biologiques, Université Houphouët-Boigny d'Abidjan, Côte \\ d'Ivoire
}

*Auteur correspondant : E-mail:e@yahoo.frTel: (225) 07494409

Justificatif: Dans le souci de valoriser les remèdes de santé issus de la médecine traditionnelle et ainsi répondre à la politique d'intégration de la médecine traditionnelle dans le système national de santé en Côte d'Ivoire, nous avons entrepris d'évaluer l'efficacité, l'innocuité et la qualité d'un remède traditionnel de santé portant le nom de code SA01 et constitué d'extraits aqueux de plantes dont Cassia occidentalis, Aloe vera, etOcimum basilicum. Nous avons évalué l'activité antalgique, puis recherché la contamination microbienne, et déterminé la toxicité aiguë.

Matériel et methods: L'évaluation de l'activité antalgique s'est faite par le test de contorsions abdominales chez la souris, le test de contamination microbienne a été faite selon l'essai de dénombrement microbien, et le test de la toxicité aiguë chez le rat selon l'essai OCDE.

Résultats: Aux doses de $5.10^{-9} \mathrm{mg}$ à $5.10^{-1} \mathrm{mg} / \mathrm{ml}$ le remède a inhibé les contorsions de $76,23 \%$ à $81,23 \%$ respectivement. Le paracétamol à la dose de $10 \mathrm{mg} / \mathrm{kg}$ de pc, a inhibé les contorsions à 38,6 \%. Le dénombrement des germes aérobies mésophiles s'est élevé à $2.10^{5} \mathrm{UFC} / \mathrm{ml}$. A la dose de $2000 \mathrm{mg} / \mathrm{kg}$ de pc, le remède n'a pas entrainé de mort chez le rat, ni de comportements anormaux.

Conclusion: Le remède SA01 possède des vertus analgésiques potentielles. L'absence de létalité à la dose de 5000mg/kg de pc permet de classer le remède SA01 selon le Système Général Harmonisé de Classification des Substances Chimiques parmi les produits ne renfermant pas de substances toxiques ni nocives chez l'homme. Mais la présence de germes mésophiles non pathogènes diminue la qualité marchande du remède. Une amélioration de l'hygiène au cours de la préparation du remède est donc nécessaire. Des études plus élaborées pourraient permettre de mettre à la disposition de la population un remède de santé fiable et à coût réduit.

Mots clés : Plantes médicinales, efficacité, toxicité, qualité

\section{P-05}

\section{ANTIHYPERGLYCEMIC EFFECT OF PARINARI CURATELLIFOLIA AND ITS FLAVONOIDS RICH EXTRACTS ON STZ-INDUCED DIABETIC WISTAR RATS.}

\author{
*Olamide Crown, Afolabi Akinmoladun, Adeyosola Ayeni, Tolulope Olaleye, Afolabi Akindahunsi \\ ${ }^{l}$ Department of Biochemistry, Federal University of Technology, Akure
}

"Corresponding author:lammiecrown@gmail.com

Background:Parinari curatellifolia (PC)ex. Benth (Chrysobalanceae) grows in the savannah and rain forest of West Africa. The seed is used ethnobotanically for the treatment of pile, diabetes and hypertension. The anti-diabetic effect of aqueous methanolic extract (CE) and its flavonoid rich extract (FE) was evaluated in streptozotocin (STZ)-induced diabetic rats.

Methods; $\quad$ STZ $(65 \mathrm{mg} / \mathrm{kg}$ i.p single dose) in ice cold buffer $\mathrm{pH} 4.5$ was administered intraperitoneally to the experimental groups followed by the oral administration of CE $(150 \mathrm{mg} / \mathrm{kg})$ and FE $(30 \mathrm{mg} / \mathrm{kg})$ starting 72 hours later and for the next 28 days to normal and experimental rats. The control and the induced groups were given distilled water throughout the period of experiment. The 28 


\title{
WANNPRES 2014 ABSTRACTS Afr J Tradit Complement Altern Med. (2015) 12(S):1-44 http://dx.doi.org/10.4314/ajtcam.v12i5.1S
}

anti-diabetic potential was assessed by determining fasting blood glucose, plasma glucose and lipid profile, liver glycogen and activities of hepatic glucose-6-phosphate dehydrogenase (G6PDH), hexokinase as well as activity of lactate dehydrogenase (LDH) in the plasma.

Results: The results revealed that intoxication caused a significant increase in the blood glucose, plasma levels of glucose, cholesterol, triglycerides, low density lipoprotein (LDL) and activities of LDH while liver glycogen, plasma high density lipoprotein (HDL) and activities of G6PDH and hexokinase were reduced significantly. Treatment with the extracts ameliorated the effects of STZ on these parameters. The antidiabetic potential of the extracts compared well with glibenclamide.

Conclusion: Thus the findings of this study highlight the potentials of Parinari curatellifolia in diabetes and its cardiovascular complications due to its anti-diabetic and anti-hyperlipidemic properties, thereby justifying its traditional use for the treatment of pile diabetes and hypertension.

\section{P-06}

\section{ANTIMALARIAL ACTIVITY AND TOXICOLOGICAL PROFILES OF THE METHANOLIC EXTRACTOF CLERODENDRON POLYCEPHALUM LEAVES ON PLASMODIUM BERGHEI IN MICE.}

\author{
Adewoyin, F. B..$^{1 *}$, Omisore, N. O. ${ }^{2}$, Odaibo, A. B. ${ }^{3}$, Adewunmi, C. O. ${ }^{1}$ Iwalewa, O. E. ${ }^{4}$ \\ ${ }^{1}$ Drug Research and Production Unit, ObafemiAwolowoUniversity \\ ${ }^{2}$ Department of Pharmacology, ObafemiAwolowoUniversity, \\ ${ }^{3}$ Department of Zoology, ObafemiAwolowoUniversity \\ ${ }^{4}$ Department of Pharmacology, University of Ibadan, Nigeria.
}

*Corresponding author: Email: adewoyin @ oauife.edu.ng

Background: In traditional medicine, the leaves of Clerodendron polycephalum are usually boiled in water and taken as remedy for malaria. It is therefore imperative to ascertain its efficacy and safety.

Methodology: The methanolic extract of the leaves was investigated for its prophylaxis, suppressive and curative effects on Plasmodium berghei in mice using standard methods. For both suppressive and curative effects, animals were treated with $100-600$ $\mathrm{mg} / \mathrm{kg}$ of the extract and chloroquine $(10 \mathrm{mg} / \mathrm{kg}$ ) as positive control. Prophylactic test animals received $200-600 \mathrm{mg} / \mathrm{kg}$ of extract while the positive control group was given pyrimethamine $(1.2 \mathrm{mg} / \mathrm{kg}) .0 .9 \%$ Normal saline was used as negative control. All doses were administered orally. Sub-chronic oral toxicity was done and observations made on morbidity, mortality and haematological parameters.

Results: At $100-600 \mathrm{mg} / \mathrm{kg}$, prophylaxis and suppressive tests exhibited $57.46-91.56 \%$ and $57.86-92.63 \%$ chemosuppression respectively. The curative test produced concentration dependent chemosuppression from day 3 - day 7 ; at $600 \mathrm{mg} / \mathrm{kg}$, chemosuppression increased from 71.35 (day 3 ) to $86.37 \%$ (day 7). Positive controls significantly compared well with the activities of the extract $(\mathrm{p}<0.05)$. The incidence of increase in body weights of test animals, after an initial decrease following extract administration, could be inferred as possible recovery from any toxic activity of the extract. Furthermore, slight differences $(\mathrm{p}<0.05)$ were observed in some of the values of the haematological parameters (red blood cell count, packed cell volume, haemoglobin estimation) compared to the control.

Conclusion: The study confirmed its efficacy and its use as antimalaria remedy could be declared safe. 
WANNPRES 2014 ABSTRACTS Afr J Tradit Complement Altern Med. (2015) 12(S):1-44 http://dx.doi.org/10.4314/ajtcam.v12i5.1S

$\mathbf{P - 0 7}$
FLAVONOID GLYCOSIDES AND ANTI-INFLAMMATORY PROPERTIES OF METHANOL EXTRACT OFPTEROCARPUS ERINACEUS POIR. (FABACEAE) LEAVES

\begin{abstract}
Ouédraogo N. ${ }^{1,2,3}$, Sawadogo R. W. ${ }^{1}$, Tibiri A. ${ }^{1}$, Lompo M. ${ }^{1}$, Hay A.E. ${ }^{3}$, Koudou J. ${ }^{2}$, Dijoux M-G. ${ }^{3}$ and Guissou I. P..$^{1,2}$
${ }^{I}$ Département de médecine-pharmacopée traditionnelle/pharmacie (IRSS/CNRST) 03 BP 7192 Ouagadougou 03, Burkina Faso

${ }^{2}$ Laboratoire de pharmacologie et toxicologie, UFR/SDS, Université de Ouagadougou 03 BP 7021 Ouagadougou 03, Burkina Faso

${ }^{3}$ Université de Lyon, F-69622, Lyon, France; Université Lyon 1, Villeurbanne; CNRS, UMR 5557, Ecologie Microbienne, CESN,
\end{abstract} ISPB, 69373 Lyon, France

*Corresponding author: ouednouf@gmail.com Tel:00226 70280673

Background: Leaves of Pterocarpus erinaceus Poir. (Fabaceae) are used in Burkina Faso folk medicine to treat ulcer, anemia, fever, parasitosis and bacterial and virus diseases. In this study we investigated the anti-inflammatory effect of the methanol extract of the leaves of $P$. erinaceus on mice paw oedema induced by carrageenan and on LPS-stimulated RAW 264.7 cells through tumour necrosis factor alpha (TNF $\alpha$ ) and nitric oxide (NO) production.

Methods: The methanol extract was fractionated using standard chromatographic techniques 9thin layer chromatography (TLC), solid phase extraction (SPE), column chromatography (CC), vacuum liquid chromatography (VLC), Medium Pressure Liquid Chromatography (MPLC) and High Performance Liquid Chromatography (HPLC) and the isolated pure compounds were characterised using nuclear magnetic resonance technique (1D and 2D NMR).

Results: Oral administration of methanol extract of Pterocarpus erinaceus the leaves reduced significantly ( $<<0.05)$ paw oedema induced by carrageenan injection at $400 \mathrm{mg} / \mathrm{kg}$ b.w. Leaves methanol extract $(50 \mu \mathrm{g} / \mathrm{mL})$ inhibited NO and TNF $\alpha$ production in LPSstimulated RAW 264.7 cells at $95 \%$ and $37.35 \%$ respectively. Chromatographic fractionation led to the isolation of some flavonoids namely: rutin, quercetin-3- $O$-sophorosid, kaempferol-3- $O$-sophorosid and quercetin-3-O- $\beta$-glucose. This study demonstrated the antiinflammatory effect of Pterocarpus erinaceus leaves through edema inhibition, and TNF $\alpha$ and NO reduction.

Conclusion: The isolated flavonoids could be responsible of pharmacological proprieties of $P$. erinaceus leaves. All these results give scientific basis of the uses of $P$. erinaceus in traditional medicine.

Key words: Pterocarpus erinaceus, anti-inflammatory, NO and TNF $\alpha$, flavonoids

\title{
P-08
}

ANTI-INFLAMMATORY ACTIVITIES OF FRUIT AND LEAVES EXTRACT OF LANNEAMICROCARPA ENGL. \& K. KRAUS (ANACARDIACEAE)

Bationo Jean Hubert ${ }^{\mathrm{a}}$, Hilou Adama ${ }^{\mathrm{a}}$, Compaore Moussa ${ }^{\mathrm{a}}$, Coulibaly Y Ahmed ${ }^{\mathrm{a}}$, Yougbare Ziebrou Mouhibatou ${ }^{\mathrm{b}}$, Ouedraogo Noufou ${ }^{b}$, Lompo Marius ${ }^{b}$, Kiendrebeogo Martin ${ }^{a}$, Nacoulma Odile Germaine ${ }^{a}$

a.Laboratoire de Biochimie et Chimie Appliquee (LABIOCA), UFR/SVT, Universite de Ouagadougou, 09 BP 848 Ouagadougou 09, Burkina Faso. 30

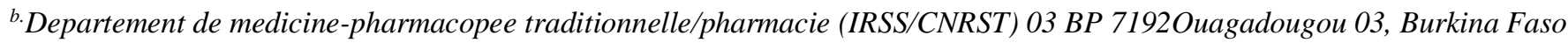




\title{
WANNPRES 2014 ABSTRACTS Afr J Tradit Complement Altern Med. (2015) 12(S):1-44 http://dx.doi.org/10.4314/ajtcam.v12i5.1S
}

*Corresponding author: eanhubat@yahoo.fr Tel :+226 70062326

Background: Lannea microcarpa is an edible fruit, which is also used for medicinal purposes. The objective of this study is to investigate the anti-inflammatory activity as well as carotenoid content of crude hydro-acetone extract of fruit and leaves of Lannea microcarpa and to elucidate the possible anti-inflammatory mechanism by enzymatic and non-enzymatic methods.

Methods: Anti-inflammatory activity was determined by using carrageenan-induced paw oedema in mice; the anti-inflammatory mechanism was assessed using the inhibitory effect of the extracts, on the lipoxygenase, xanthine oxidase, lipid peroxidation and on the reduction of $\mathrm{Fe}^{3+}$.

Result: At the doses of $100 \mathrm{mg} / \mathrm{kg}, 200 \mathrm{mg} / \mathrm{kg}, 400 \mathrm{mg} / \mathrm{kg}$, the extracts of both fruit and leaves reduced the carrageenan-induced paw oedema while the dose of $200 \mathrm{mg} / \mathrm{kg}$ produced a maximum percentage of inhibition of mice paw oedema both for fruit $(78.44 \%)$ and leaves $(58.02 \%)$ at the fifth hour compared to control. Significant lipoxygenase and xanthine oxidase inhibitory effect were obtained with the ethyl acetate fraction of both the fruit and leaves extract. Ethyl acetate fraction from both extracts inhibited lipid peroxidation. The ethyl acetate fraction of the fruit and leaves extracts also inhibited lipid peroxidation with $32.85 \%$ and $78.07 \%$ respectively. Crude acetone extract of leaves of Lannea microcarpa showed a significant reducing power of $\mathrm{Fe}^{3+}$ by $9.46 \pm 0.26$ and a high carotenoids content compared to those of fruit extract.

Conclusion: The results obtained from the present study suggest that Lannea microcarpa fruit and leaves extract possess significant anti-inflammatory and antioxidant capacities. Therefore, they could be useful for food and the pharmaceutical industry.

\section{P-09}

\section{EVALUATION DES PROPRIÉTÉS ANTIOXYDANTES DE SIX PLANTES MÉDICINALES UTILISÉES CONTRE LES MALADIES HÉPATIQUES DANS LA RÉGION DES CASCADES AU BURKINA FASO.}

\author{
Sombié, N.E., Tibiri, A., Ouédraogo, N., Traoré, K.T., N'Do, J, Hilou, A., Nacoluma, O.G. \\ Laboratoires de Chimie et de Pharmacologie/ MEPHATRA-PH/IRSS, Laboratoire de Biochimie et de Chimie Appliquée \\ (LABIOCA)/Université de Ouagadougou. \\ *Corresponding author: ernestsombie@yahoo.fr
}

Background: La présente étude porte sur l'évaluation des propriétés antioxydantes de six plantes médicinales, Cassia sieberiana DC. (Caesalpiniaceae), Diospyros mespiliformis Hochst ex.A.DC (Ebenaceae), Lophira lanceolata Tiegh.ex Keay (Ochnaceae), Piliostigma thonningii (Schum.) Milne-Redh (Caesalpiniaceae), Sarcocephalus latifolius (Sm.) E.A.Bruce (Rubiaceae) etTerminalia macroptera Guill. \& Perr (Combretaceae), utilisées en médecine traditionnelle dans la région des Cascades au Burkina Faso contre les maladies hépatiques.

Méthodes : Les activités antioxydantes de neuf extraits aqueux des six plantes ont été évaluées en utilisant trois méthodes : la décoloration du radical cation ABTS (acide 2’2, azino-bis-(3-éthylebenzothiazoline)-6-sulfonique), pouvoir réducteur du fer (FRAP) et le test d'inhibition de la peroxydation lipidique. Les teneurs en composés phénoliques ont été également déterminées.

Résultats : Les résultats ont révélé de très bonnes activités antioxydantes des feuilles de Diospyros mespiliformis, des écorces de racines de Lophira lanceolata et de Terminalia macroptera. Les meilleures teneurs en phénoliques totaux ont été obtenues avec les extraits des feuilles de Diospyros mespiliformis, des écorces de racines de Lophira lanceolata et de Terminalia macroptera. De plus 
WANNPRES 2014 ABSTRACTS Afr J Tradit Complement Altern Med. (2015) 12(S):1-44 http://dx.doi.org/10.4314/ajtcam.v12i5.1S

l'activité antioxydante (ABTS) est positivement corrélée avec les teneurs en phénoliques totaux et tanins exprimées en équivalent acide tanique pour 100 grammes de matière sèche avec respectivement $R^{2}=0,63$ et $R^{2}=0,75$.

Conclusion : Ces résultats montrent que les extraits contiennent des composés bioactifs, flavonoïdes, tanins, doués d'une forte activité antioxydante. Ils pourraient justifier l'utilisation de ces plantes en médecine traditionnelle contre les maladies hépatiques.

Mots clés : plantes médicinales, région des Cascades, Burkina Faso, maladies hépatiques, activité antioxydante.

\title{
P-10
}

\section{SCREENING OF ANTIOXIDANT ACTIVITIES OF SIX (6) PLANTS USED IN TRADITIONAL MEDICINE FOR THE TREATMENT OF HEPATIC DISEASES IN THE HAUTS-BASSINS REGION OF BURKINA FASO}

\author{
Traoré, K.T ${ }^{1}$., Tibiri, ${ }^{1,2}$., Ouédraogo, $\mathbf{N}^{1}$., Sombié, N.E ${ }^{1,2}$., N'Do, $\mathbf{J}^{1,2}$. Guissou I. P. \\ ${ }^{1}$ Laboratory of Chemistry and Pharmacology / MEPHATRA-PH/IRSS, 03 BP 7192 Ouagadougou 03 Burkina Faso \\ ${ }^{2}$ Laboratory of Biochemistry and Applied Chemistry (LABIOCA) / University of Ouagadougou. \\ *Corresponding author: charlkady@gmail.com
}

Background: The study sets out to evaluate the potential antioxidant properties of the following plants used in traditional medicine for the treatment of liver diseases in the Hauts-basins region in Burkina Faso: Anogeissus leiocarpus (DC.) Guill.\& Perr (Combretaceae), Balanites aegyptica Delie. (Zygophylaceae), Cassia alata L. (Ceasalpiniaceae), Opilia celtidifolia (Guill. \& Perr.)Endl.(Opiliaceae), Terminalia macroptera Guill.\& Perr. (Combretaceae) etZiziphus mauritiana L. (Rhamnaceae).

Methods: The antioxidant activity of aqueous extracts of the plant was evaluated by three complementary methods: the discoloration of cation radical ABTS (acid 2' 2, azino-bis-(3-éthylebenzothiazoline)-6-sulfonique), the reduction of iron (FRAP) and the inhibition test of the lipidic peroxidation. The phenolic compound content was determined

Results: Anogeissus leiocarpus, Terminalia macroptera and Ziziphus mauritiana showed better antioxidant activities and a high level of phenolic compound content (total phenolic, total flavonoids, tannins and total flavonols). The antioxidant activity using FRAP and ABTS method was correlated (respectively $R^{2}=0.8347, R^{2}=0.468$ ) with the content of total phenolic extracts expressed as tannic acid equivalent per $100 \mathrm{~g}$ of dry matter.

Conclusion: These plants have shown best antioxidant activity and high amount of phenolic compound thus they could be potential sources of natural antioxidants for the treatment of hepatic pathologies.

Keywords: liver disease, medicinal plants, Burkina Faso, antioxidant activity

P-11

ANTIOXIDANT PROPERTIES OF FRACTIONS FROM HYDROALCOHOLIC EXTRACT OF STEM BARK OF KHAYA SENEGALENSIS A. JUSS (MELIACEAE)

Traoré M.R., Ouédraogo N., Lompo M., Tibiri A., Guissou I.P., Laboratory of Chemistry and Pharmacology / MEPHATRA-PH/IRSS, 03 BP 7192 Ouagadougou 03 Burkina Faso

Corresponding author: Email:trakiatou@yahoo.fr 


\title{
WANNPRES 2014 ABSTRACTS Afr J Tradit Complement Altern Med. (2015) 12(S):1-44 http://dx.doi.org/10.4314/ajtcam.v12i5.1S
}

Background: Khaya senegalensis A.Juss (Meliaceae) is used to several diseases (rheumatism, ulcer, malaria, infectious diseases) in folk medicine at Burkina Faso. The present study was conducted to evaluate the phenolic content and antioxidant activity of the fractions (hexane, ethyl acetate, $n$-butanol, distilled water) from hydroalcoholic extract of stem bark of Khaya senegalensis A. Juss (Meliaceae).

Methods: Four methods including reducing the radical DPPH (2, 2-diphenyl -1- picrylhydrazyl ), radical cation ABTS ( 2'2 acid azino -bis (3- éthylebenzothiazoline )-6- sulfonic acid), the reduction of iron ( FRAP ) and the inhibition test of the lipid peroxidation was used to evaluate antioxidant activity. The phenolic content was assayed by using the Folin Ciocalteu Reagent (FCR) and aluminum trichloride $\left(\mathrm{AlCl}_{3}\right)$.

Results: The butanol fraction had high amounts of total phenolic (74.95 $\pm 4.41 \mathrm{gEAT} / 100 \mathrm{~g})$ and flavonoid $(0.90 \pm 0.10 \mathrm{gEQ} / 100 \mathrm{~g})$, while tannins $(46.80 \pm 3.11 \mathrm{gEAT} / 100 \mathrm{~g})$ and flavonols $(1.69 \pm 0.22 \mathrm{gEQ} / 100 \mathrm{~g})$ were more in the aqueous fraction. The highest potential antioxidant was obtained with the butanol fraction using the DPPH and FRAPS methods. Also, the DPPH radical scavenging activity correlated well with total phenolics $\left(R^{2}=0.9824\right)$ and with flavonols $\left(R^{2}=0.9993\right)$.

Conclusion: The results show that the hydroalcoholic extract and fractions had important phenolic compounds such as tannins and had an antioxidant potential. This phytochemical composition and antioxidant capacity justify the use of the Khaya senegalensis by traditional healers, to treat inflammatory disease.

Key words: Khaya senegalensis, antioxidant activity, phenolic compounds.

\section{P-12}

CYTOTOXIC EFFECTS OF AQUEOUS EXTRACT OF ROOT BARK OF CALOTROPIS PROCERA (AIT.) R. BR (ASCLEPIADACEAE), PLANT USED IN TRADITIONAL MEDICINE IN BURKINA FASO

\author{
Geoffroy G. Ouedraogo ${ }^{1,2^{*}}$; Serge Moukha ${ }^{2}$; Théophile A. Mobio ${ }^{2}$, Moustapha Ouedraogo ${ }^{1}$, Pierre I. Guissou ${ }^{1,3}$ and \\ EdmondE. Creppy ${ }^{2}$ \\ ${ }^{1}$ Laboratoire de Toxicologie, Environnement et Santé ; Ecole Doctorale de la Santé, Université de Ouagadougou, 03 BP 7021 \\ Ouagadougou 03, Burkina Faso. \\ ${ }^{2}$ Laboratoire de Toxicologie et d'Hygiène Appliquée, UFR des sciences pharmaceutiques, Université Bordeaux-2, 146 rue Leo \\ Saignat, 33076 Bordeaux, France. \\ ${ }^{3}$ Institut de Recherche en Sciences de la Santé / Centre National de Recherche Scientifique et Technologique (IRSS/CNRST), 03 BP \\ 7192 Ouagadougou 03, Burkina Faso.
}

Corresponding author: E-mail: guioffray@yahoo.fr; Tel. (00226) 700915 03/ 78805439

Background: Calotropis procera (Ait.) R. Br (C. procera) commonly called "Pomme de Sodome" in French is a species widely used in traditional medicine for the treatment of various diseases such as sickle cell disease, asthma and cancer. This wild plant belonging to the family of Asclepiadaceae is distributed in tropical and subtropical Africa and Asia and grows typically in arid environments rich in phosphorus and calcium such as cemeteries. Different parts of this plant are used for different purposes such as treatment of diverse diseases but also widespread in magico-religious practices. The objective of this study was to evaluate the in vitro cytotoxicity of the aqueous extract of the bark of the plant roots on cancer cells.

Methods: Caco-2 cells (Human Caucasian colon adenocarcinoma) and Neuro-2a cells (mouse Albino neuroblastoma) were used in the study. (MTT), Neutral red (NR) and DNA fragmentation assay were performed to assess cytoxicity. 


\title{
WANNPRES 2014 ABSTRACTS Afr J Tradit Complement Altern Med. (2015) 12(S):1-44 http://dx.doi.org/10.4314/ajtcam.v12i5.1S
}

Results: The study revealed that the aqueous extract of the plant has cytotoxic effects on both cell lines. The $\mathrm{IC}_{50}$ values were 33 $\mu \mathrm{g} / \mathrm{mL}$ and $1802 \mu \mathrm{g} / \mathrm{mL}$ respectively for Caco-2 and Neuro-2a cells with MTT assay. Also, the $\mathrm{IC}_{50}$ values were about $13 \mu \mathrm{g} / \mathrm{mL}$ and $254 \mu \mathrm{g} / \mathrm{mL}$ by the Neutral Red test in Caco-2 and Neuro-2a cells respectively. Moreover, the extract induced DNA fragmentation of Caco -2 cell in high concentrations (50 and $100 \mu \mathrm{g} / \mathrm{mL}$ ).

Conclusion: The aqueous extract of root barks of Calotropis procera has a potential cytotoxic effect on human colorectal carcinoma Caco-2 cells. However, further studies are needed to move towards in development of an anticancer drug based on the plant.

Key words: Calotropis procera (Ait.), cytotoxicity, MTT, Neutral Red, Caco-2, Neuro -2a.

\section{P-13}

\section{THE PROXIMATE AND PHYTOCHEMICAL COMPOSITION OF SESAMUM INDICUM LINN AND CERATOTHECA SESAMOIDES ENDL AT DIFFERENT STAGES OF GROWTH}

\author{
Fasola, T.R and Ogunsola, O.K \\ Department of Botany, University of Ibadan, Nigeria
}

Corresponding author: Email: tr.fasola@ui.edu.ng

Background: Sesamum indicum and Ceratotheca sesamoides both of family Pedaliaceae were commonly harvested in substitute of one another as vegetables. These plants now belong to the group of neglected and underutilized plants as their usage have been abandoned. In order to bring to limelight the potentials of these neglected plants, their proximate and phytochemical composition were investigated.

Methods: The seeds of Ceratotheca sesamoides and Sesamum indicum were cultivated at a back yard garden of the University of Ibadan. The leaves were harvested at six, eight and ten weeks. The plants were later authenticated at the Forest Herbarium Ibadan and assigned voucher numbers. Proximate and phytochemical composition for the three stages of growth was investigated following standard methods.

Results:Significant differences were observed in the percentage proximate and phytochemical analyses of the two species at different stages of growth. Comparative studies also revealed a higher percentage proximate in S. indicum (9.57\% crude fibre, $9.53 \%$ moisture) than $C$. sesamoides $(8.67 \%$ crude fibre, $9.17 \%$ moisture) while the phytochemicals were significantly more in the $S$. indicum $(138.33 \mathrm{mg} / 100 \mathrm{~g}$ Tannins) than $C$. sesamoides $(127 \mathrm{mg} / 100 \mathrm{~g}$ Tannins). The values for the two species were at par for saponins at $330 \mathrm{mg} / 100 \mathrm{ml}$, while the other phytochemicals present had slightly higher values in $C$. sesamoides for flavonoids, alkaloids and phenols at $1315 \mathrm{mg} / 100 \mathrm{~g}, 843 \mathrm{mg} / 100 \mathrm{~g}$ and $46.3 \mathrm{mg} / 100 \mathrm{~g}$ respectively. In this study, proximate, mineral and phytochemical constituents showed a decline as the leaves approached reproductive stage of flowering and fruiting. It was noted in the two species studied that $S$. indicum started flowering after 8 weeks of growth and $C$. sesamoides, between the $9^{\text {th }}$ and the $10^{\text {th }}$ week.

Conclusion: The proximate and the phytochemical values of the plants strongly support their use as vegetables and suggestive of medicinal values hence should not be neglected. This work will serve to guide the users of the plant at various stages of harvesting for particular phytochemical of choice. 
WANNPRES 2014 ABSTRACTS Afr J Tradit Complement Altern Med. (2015) 12(S):1-44 http://dx.doi.org/10.4314/ajtcam.v12i5.1S

\title{
P-14
}

IN VITRO ANTIBACTERIAL AND ANTIFUNGAL ACTIVITY OF OPILIA CELTIDIFOLIA (OPILIACEAE)

\author{
Yougabaré Sibidou ${ }^{1}$, Yerbanga Serges ${ }^{2}$; Tahita Marc ${ }^{1}$, Lompo Palpougouni ${ }^{1}$, Traoré/Coulibaly Maminata1 \\ ${ }^{1}$ Intitut de Recherche en Sciences de la Santé (IRSS- DRO) \\ ${ }^{2}$ Université Catholoique de l'Afrique de l'Ouest UCAO
}

Corresponding author: ganyaiga@hotmail.fr

Background:Opilia celtidifolia is a plant used in the central part of Burkina Faso in the treatment of bad skin diseases. The local name «waagsalga» refers to this use. This study was undertaken to investigate the antibacterial and antifungal activities of the plant on a series of organisms involved in skin diseases.

Methods: Three samples of $O$. celtidifolia from two different sites were collected. Organic and aqueous extracts were prepared. Three bacterial and two fungal strains were used for the biological assays. The antimicrobial activity of the extracts was assessed using the Agar diffusion method and the zones of inhibition determined. The minimum inhibitory concentrations (MIC) and minimal bactericidal concentration (MBC) of active extracts were determined according to the microdilution method.

Results: The tested extracts gave different inhibition zones. The dichloromethane extract of the roots was the most active on $S$. agalactiae with a MIC estimated to $73.2 \mu \mathrm{g} / \mathrm{ml}$. The ethanolic extracts of the roots and the stem of the plant were active to inhibit the growth of cocci bacteria but were unable to inhibit bacillus bacteria and fungi. The decocted aqueous extracts displayed a weak activity against all the strains. The phytochemical analysis of the extracts revealed the presence of diverse chemical groups which may explain the difference activity observed between the extracts.

Conclusion: The inhibitory activity displayed by the extracts from Opilia celtidifolia may justify the traditional use of the plant in the treatment of some bad skin diseases.

Key words: Phytotherapy, bacterial and fungal dermatosis, Opilia celtidifolia, antimicrobial activity

P-15

ETUDE PHARMACOGNOSIQUE DE OCIMUM GRATISSIMUMLINN., PLANTE ALICAMENT FOFIE Yvette Bra N'Guessan ${ }^{1 *}$, COULIBALY KiyinIma² ${ }^{2}$ KONE-BAMBA Diénéba ${ }^{1}$

${ }^{I}$ UFR Sciences Pharmaceutiques et Biologiques, Université Félix Houphouët Boigny de Cocody-Abidjan; 22 BP 747 Abidjan 22, Côte d'Ivoire.

${ }^{2}$ UFR des Sciences Biologiques, Université Péléforo Gon Coulibaly, BP 1328 Korhogo, Côte d'Ivoire.

Objectif: Étudier les caractéristiques préliminaire et pharmacognosique de Ocimum gratissimumLinn., plante médicinale, utilisée comme aliment dans des régions de l'Afrique de l'ouest. 
WANNPRES 2014 ABSTRACTS Afr J Tradit Complement Altern Med. (2015) 12(S):1-44 http://dx.doi.org/10.4314/ajtcam.v12i5.1S

Méthodes: L'étude pharmacognosique a permis des examens macroscopiques et microscopiques de la drogue fraîche et sèche. L'étude des paramètres physico-chimique a consisté en la détermination de l'humidité, des cendres totales, sulfuriques et insolubles dans l'acide chlorhydriques.

Résultats: L'examen pharmacognosique a révélé une petite plante avec des petites feuilles pétiolées opposées, ovales et dentées. Les fruits sont en forme de petites capsules. La coupe anatomo-histologique, a montré des poils tecteurs, des cellules palissadiques, des parenchymes lacuneux, un appareil vasculaire en arc. Sur la tige sont observé des tissus primaires, un parenchyme fondamental. La micrographique a présentée des cellules à huile, des faisceaux spiralés ainsi que desfaisceaux de bois spiralés.

Conclusion:L'analyse pharmacognosique et les caractéristiques physico-chimiques peuvent aider la pharmacopée à une utilisation efficiente de cette plante.

Mots clefs: Pharmacognosie, alicaments, Ocimum gratissimum Linn

\title{
P-16
}

\section{QUANTITATIVE PHYTOCHEMICAL SCREENING OF THREE MEDICINAL SPECIES OF THE GENUS JATROPHA IN NIGERIA.}

\author{
Kolawole, O.S. ${ }^{{ }^{*}}$; Omokanye, B.S. ${ }^{2}$; Ayesa, S. A ${ }^{3}$ and Adewumi, G. A. ${ }^{2}$ \\ ${ }^{I}$ Department of Biological Sciences, Faculty of Science, FederalUniversity, Kashere, GombeState. \\ ${ }^{2}$ Department of Plant Biology, Faculty of Life Science, University of Ilorin, IlorinKwaraState. \\ ${ }^{3}$ Department of Botany, Faculty of Science, University of Ibadan, Ibadan, OyoState.
}

*Corresponding Author: kolawolesaheed@ fukashere.edu.ng ; +2348060909011

Background: Medicinal plants play great role and importance to the health ofindividuals and communities. Different species of Jatropha are used in the management diseases and ailments in Nigeria. This study investigated the phytochemical presents in the leaves of Jatrophacurcas Linn. , Jatrophagossypifolia Linn. andJatrophamultifida Linn. in other to evaluate the quantitative secondary metabolites in each medicinal species of the Jatropha in Nigeria.

Materials and Methods: Specimens were collected in different locations in Nigeria and identified at the Forest Herbarium, Ibadan (FHI). The leaves were air dried, ground into fine powder and subjected to series of phytochemical screening using standard methods.

Results: Results shows that phenols contents was the highest in the three (3) plant species investigated J. curcas with $35.81 \%$ $(5.92 \pm 0.06 \mathrm{mg} / \mathrm{g}) ; J$. gossypifolia $46.61 \%(16.17 \pm 0.55 \mathrm{mg} / \mathrm{g})$ while $J$. multifida has $37.74 \%(8.72 \pm 0.32 \mathrm{mg} / \mathrm{g})$. The results also revealed that tannins, flavonoids and phenols are in large quantity. The alkaloid content is $0.69 \pm 0.07 \mathrm{mg} / \mathrm{g}$ in $J$. curcas; $1.11 \pm 0.02$ $\mathrm{mg} / \mathrm{g}$ in $J$. gossypifolia and $0.88 \pm 0.04 \mathrm{mg} / \mathrm{g}$ in $J$. multifida. There were no significant amount of phytosteroids, cardiac glycosides, saponins and terpenoids in the leaves of the studied species.

Conclusion: This study reveals that leaves the species studied contains important compounds which may be useful in medicine and also justifies the traditional uses of the plant in Nigeria for various ailments.

Key words: Genus Jatropha, Phytochemical screening, Medicinal plants, leaves, Phytocompounds 
WANNPRES 2014 ABSTRACTS Afr J Tradit Complement Altern Med. (2015) 12(S):1-44 http://dx.doi.org/10.4314/ajtcam.v12i5.1S

\title{
P-17
}

\section{SERUM GLUCOSE AND LIPID LOWERING ACTIVITY OF THE LEAF EXTRACT OF ALCHORNEA CORDIFOLIA (SCHUM. \& THONN.)MUELL. ARG IN DEXAMETHASONE-INDUCED DIABETIC RAT MODEL}

\author{
AK Thomford ${ }^{1 *}$, KP Thomford ${ }^{2}$, F Ayertey ${ }^{2}, J_{\text {Aseidu-Larbi }}^{2}$, KA Thomford ${ }^{3}$, EO Ameyaw ${ }^{1}, J_{N}$ Boampong $^{1}$, DA Edoh $^{2}$, M \\ Enimil $^{1}$, SA Bioh ${ }^{1}$ \\ ${ }^{1}$ Department of Biomedical and Forensic Sciences, University of Cape Coast, Ghana \\ ${ }^{2}$ Centre for Plant Medicine Research, Mampong-Akwapim, Ghana \\ ${ }^{3}$ Greater AccraRegionalHospital, Accra-Ghana \\ "Corresponding author: akthomford@ outlook.com
}

Background: Poor lipid and glucose regulation increases the risk for the development of major cardiovascular diseases and other organ damage.

Objective: The study evaluated the serum glucose and lipid lowering effects of the $70 \%(\mathrm{v} / \mathrm{v})$ ethanolicleaf extract of Alchornea cordifolia (ALC) using the dexamethasone-induced diabetic rat model.

Methods: Female Sprague-Dawley rats distributed into 5 groups $(n=5)$ were rendered hyperglycaemic with dexamethasone (10 $\mathrm{mg} / \mathrm{kg}, \mathrm{sc}$ ) once daily for 8 days except the normal control (n=5). Each group received normal saline $0.5 \mathrm{ml} / \mathrm{rat}$, ALC ( $250 \mathrm{mg} / \mathrm{kg}, \mathrm{p} .0$. or $500 \mathrm{mg} / \mathrm{kg}$, p.o.), glibenclamide $(5 \mathrm{mg} / \mathrm{kg}$, p.o.) or atorvastatin $(5 \mathrm{mg} / \mathrm{kg}$, p.o.) as treatment once daily for 8 days. Fasting blood glucose (FBS) readings were recorded at baseline, day 4, 6 and 9. Blood was collected for the estimation of serum triglycerides (TG), total cholesterol (TC), low density lipoproteins (LDL), very low density lipoproteins (VLDL) on day 9.

Results:The dexamethasone group showed significantly raised FBS levels $(8.20 \pm 1.04 \mathrm{mmol} / \mathrm{l} ; * * * p<0.0001)$ throughout the experiment. Glibenclamide prevented an increase in FBS level by day 4, though not significant until day $9(* * * p<0.0001)$. The extracts [(ALC $250 \mathrm{mg} / \mathrm{kg}$, p.o.; $\left.(5.35 \pm 0.95 \mathrm{mmol} / \mathrm{l}) ;{ }^{*} p<0.05\right) ;$ ALC $500 \mathrm{mg} / \mathrm{kg}$, p.o.; $\left.\left.(4.45 \pm 1.65 \mathrm{mmol} / \mathrm{l}) ;{ }^{*} p<0.05\right)\right]$ however controlled the FBS level at day 9. The dexamethasone group also recorded TG $(2.13 \pm 0.30 \mathrm{mg} / \mathrm{dl} ; * * * p<0.0001)$, TC $(3.58 \pm 0.41$ $\mathrm{mg} / \mathrm{dl} ; * * * p<0.0001), \operatorname{LDL}(1.36 \pm 1.23 \mathrm{mg} / \mathrm{dl} ; * * * p<0.0001)$ and VLDL $(0.55 \pm 0.04 \mathrm{mg} / \mathrm{dl} ; * * p<0.0001)$ when compared with normal control. Atorvastatin alsorecorded TG $(1.46 \pm 0.08 \mathrm{mg} / \mathrm{dl} ; * * p<0.001)$, TC $(1.76 \pm 0.06 \mathrm{mg} / \mathrm{dl} ; * * * p<0.0001)$, LDL $(1.17 \pm$ $0.04 \mathrm{mg} / \mathrm{dl} ; p>0.05)$ and VLDL $(0.34 \pm 0.04 \mathrm{mg} / \mathrm{dl} ; p>0.05)$ when compared to the dexamethasone group.

The effect of the extracts on serum lipids were: TG [ALC $250 \mathrm{mg} / \mathrm{kg}$, p.o., $(1.06 \pm 0.17 \mathrm{mg} / \mathrm{dl} ; * * * p<0.0001)$; ALC $500 \mathrm{mg} / \mathrm{kg}$, p.o., $(0.60 \pm 0.03 \mathrm{mg} / \mathrm{dl} ; * * * p<0.0001)]$, TC [ALC $250 \mathrm{mg} / \mathrm{kg}$, p.o., $(1.86 \pm 0.36 \mathrm{mg} / \mathrm{dl} ; * * * p<0.0001) ;$ ALC $500 \mathrm{mg} / \mathrm{kg}$, p.o., $(1.37 \pm 0.11$ $\mathrm{mg} / \mathrm{dl} ; * * * p<0.0001)$ ], LDL [ALC $250 \mathrm{mg} / \mathrm{kg}$, p.o., $(1.07 \pm 0.20 \mathrm{mg} / \mathrm{dl} ; p>0.05) ;$ ALC $500 \mathrm{mg} / \mathrm{kg}$, p.o., $(0.69 \pm 0.09 \mathrm{mg} / \mathrm{dl} ; * p<0.01)$ ] and VLDL [ALC $250 \mathrm{mg} / \mathrm{kg}$, p.o., $(0.45 \pm 0.04 \mathrm{mg} / \mathrm{dl} ; p>0.05)$; ALC $500 \mathrm{mg} / \mathrm{kg}$, p.o., $\left(0.27 \pm 0.01 \mathrm{mg} / \mathrm{dl} ; *^{*} p<0.05\right)$ ] when compared to the dexamethasone group.

Conclusion: The $70 \%(\mathrm{v} / \mathrm{v})$ ethanolicleaf extract of Alchornea cordifolia has somepotential for use in lipid and glucose control.

Key words:Alchorneacordifolia, antidiabetic, antihyperglycaemic, antihyperlipidaemic, atorvastatin, dexamethasone and glibenclamide 
WANNPRES 2014 ABSTRACTS Afr J Tradit Complement Altern Med. (2015) 12(S):1-44 http://dx.doi.org/10.4314/ajtcam.v12i5.1S

\title{
P-18
}

\author{
HYPOTENSIVE AND PREVENTIVE EFFECTS OF HYPERTENSIVE BLOOD BY EXTRACTS OF LANNEA \\ MICROCARPA ENGL. AND K. KRAUSE (ANACARDIACEAE); A RECIPE OF TRADITIONAL MEDICINE IN \\ BURKINA FASO
}

\author{
Nitiéma $M^{1,2}$, Belemnaba $L^{2}$, Ouédraogo $S^{1,2}$, Traoré $\mathrm{A}^{2}$., Kini B.F. ${ }^{1,2}$, Somé $\mathrm{N}^{2}$., Guissou I. $\mathbf{P}^{1,2}$. \\ 1-University of Ouagadougou - GraduateSchool of Health - Laboratory of Pharmacology \\ 2-Centre National Scientific and Technological Research - Institute for Research in Health \\ Sciences - Department of Medicine and traditional pharmacopoeia - Pharmacy
}

Corresponding author: Email:osylvin@yahoo.fr

Background:Hypertension (HTA) is a very serious disease among primary diseases in Burkina Faso.Lannea microcarpa Engl. and K. Krause is a plant used by traditional healers inBurkina Fasofor the treatment of severalpathologies including high blood pressure. In this study, we evaluate the hypotensive and preventive effects of Lannea microcarpaon anesthetized normotensive blood pressure of Wistar Rat.

Materials and methods: The aims of this study were to evaluate the hypotensive and hypertension preventive effects of the recipe of a traditional medicine in Burkina Faso in normotensive Wistar rats. The anesthetized rat method was used to evaluate hypotensive and hypertension preventive effects of plant extracts. High blood pressure was induced by adrenaline $(75 \mu \mathrm{g} / \mathrm{kg})$ and phenylephrine (100 $\mu \mathrm{g} / \mathrm{kg}$ ) administration after administering the extracts. The crude aqueous decoction and its methylene and ethyl acetate fractions from Lannea microcarpa Engl. and K. krause were tested.

Results: The pharmacological in vivo study showed that extracts induce a transient hypotensive effect on normotensive anesthetized rat in dose-dependent manner. On adrenaline and phenylephrine-induced high blood pressurerespectively, all extracts caused a dosedependent inhibitory effect by single preventive doses of 0.03 to $10 \mathrm{mg} / \mathrm{kg}$ when administered $5 \mathrm{~min}$ before the agonists. The best effects of the extracts tested have been obtained with the crude extract and the ethyl acetate fraction of Lannea microcarpa Engl. and K. krause.

Conclusion: Taken together these results are in accordance with the attending one and may justify the traditional use of these plants in the symptomatic treatment of hypertension.

Key words: Medicinal plants-Lannea microcarpa - hypertension.

P-19

ACTIVITIES OF ETHANOL ROOT EXTRACT OF MEZONEURON BENTHAMIANUM ON ORGANISMS IMPLICATED IN ORAL INFECTIONS.

\author{
Oladokun Oladeji, Felix Olorunmola* and Simeon Adesina
}

Drug Research and Production Unit, Faculty of Pharmacy, Obafemi Awolowo University, Ile-Ife.

Corresponding author: Email: folorunmola@gmail.com 


\title{
WANNPRES 2014 ABSTRACTS Afr J Tradit Complement Altern Med. (2015) 12(S):1-44 http://dx.doi.org/10.4314/ajtcam.v12i5.1S
}

Background: Mezoneuron benthamianum belongs to the family Caesalpiniaceae and is a shrub or woody climber widely used in many parts of West Africa for the treatment of infectious diseases of the skin and wound. The reported claim of the use of the root in South West Nigeria as chewing stick for the treatment of tooth pain resulting from bacterial and fungal infections of the oral cavity necessitated this study.

Methods: The ethanol extract and partitioned fractions of the powdered root were evaluated against Staphylococcus aureus (NCIB 8588), clinical isolate of Streptococcus mutans, Streptococcus pyogenes, Streptococcus salivarus, Staphylococcus aureus and Candida albicans from human oral cavity using the agar diffusion method. The minimum inhibitory concentration was determined using the two fold agar dilution method. Time kill assay and bioautographic assay of the most active fraction were also investigated by standard methods.

Results: The root extract had appreciable activity against the test organisms at varying concentrations $(25 \mathrm{mg} / \mathrm{ml}, 50 \mathrm{mg} / \mathrm{ml}, 100$ $\mathrm{mg} / \mathrm{ml}$ ) with increasing zones of inhibition as concentration increased. The ethyl acetate fraction gave the highest (20.6 - $23.7 \mathrm{~mm})$ while petroleum spirit gave the lowest zones of inhibition against the organisms. The MIC gave a rank order of ethyl acetate (0.39 $\mathrm{mg} / \mathrm{ml})<$ chloroform $(0.78-6.25 \mathrm{mg} / \mathrm{ml})<$ aqueous $(3.13-12.5 \mathrm{mg} / \mathrm{ml})<$ petroleum spirit $(6.25 \mathrm{mg} / \mathrm{ml}-25 \mathrm{mg} / \mathrm{ml})$. The time-killassay showed that ethyl acetate fraction demonstrated a rapid rate of killing of the organisms at MIC concentration (0.39 $\mathrm{mg} / \mathrm{ml}) \mathrm{while}$ doubling the MIC reduces the time of death and viable counts. At $3 \mathrm{x}$ MIC, no observable growth in 5 minutes, and this was comparable to that of the antibiotics used in this study. The chromatographic result of the ethyl acetate fraction revealed the presence of two compounds, one of which was active against all the organisms.

Conclusion: The study concluded that $M$. benthamianum ethanol root extract and its ethyl acetate fraction was highly active as antimicrobial agent, and significantly concentration dependent. This may justify its use for the treatment of oral infections.

\section{P-20}

\author{
ANTIMALARIAL AND ANTIOXIDANT ACTIVITIES OF EXTRACT AND FRACTIONS OF BORRERIA OCYMOIDES \\ (RUBIACEAE) AERIAL PARTS. \\ Orabueze, Celestina $I^{1}$; Adesegun, Sunday $A^{1^{*}}$; Ota, Duncan $A^{3}$ and Coker, Herbert $A^{2}$. \\ ${ }^{1}$ Departments of Pharmacognosy. \\ ${ }^{2}$ Pharmaceutical Chemistry, Faculty of Pharmacy, 3, \\ ${ }^{3}$ Department of Physiology, College of Medicine, University of Lagos, Nigeria.
}

Background: Malaria is an infectious disease of enormous importance in tropical countries. Despite the eradication programs, malaria is still a threat to over 2 billion people living in areas of high incidence. It is Africa's leading mortality in under five year olds and constitutes $10 \%$ of the continent's overall disease burden. The plant Borreria ocymoides is commonly used in the treatment of malaria and "re-current" fever in South-East Nigeria.

Method: In this study, the methanolic extract (aerial part) suspended in water was partitioned between hexane, dichloromethane and ethyl acetate successively to obtain various fractions that were investigated for in vivo antimalarial and in vitro antioxidant activities. The antiplasmodial effect was measured by its \% chemosuppressive effect against Plasmodium berghei berghei NK65 infected mice with artesunate and chloroquine as positive controls. Anti-oxidant activity of the extract was also assessed using 1,1-diphenyl-2picryl-hydrazile (DPPH), total phenolic content and reducing assays. 


\title{
WANNPRES 2014 ABSTRACTS Afr J Tradit Complement Altern Med. (2015) 12(S):1-44 http://dx.doi.org/10.4314/ajtcam.v12i5.1S
}

Results: The crude extract (250, 500 and $1000 \mathrm{mg} / \mathrm{kg}$, p.o.) produced 70.9, 72.2 and $52.1 \%$ inhibition respectively as against $82.1 \%$ for chloroquine $(5.0 \mathrm{mg} / \mathrm{kg}$ ) and $73.8 \%$ for artesunate $(10 \mathrm{mg} / \mathrm{kg})$. At the dose of $250 \mathrm{mg} / \mathrm{kg}$, hexane and ethyl acetate fractions exhibited moderate chemosuppresive effects (51.5.0 and $62.6 \%$ respectively) while dichloromethane and aqueous fractions gave $37.5 \%$ and $33.2 \%$ respectively. The total phenolic content was $48.7 \mathrm{mg} / \mathrm{g}$ in terms of gallic acid. The DPPH radical scavenging and reducing ability of the extract increased with concentration. The antioxidant activity was about 7 times less than ascorbic acid used as positive control. Oral administration up to $10 \mathrm{~g} / \mathrm{kg}$ produced no noticeable deleterious effect 24 hours after dosing and up to 7 days afterwards.

Conclusion: The result suggested that the crude extract exhibited higher antiplasmodial activity than the fraction, suggesting the probability of synergistic effect of the various fractions.

Key words: Antimalaria, antioxidant, chemosuppressive effect,

\section{P-21}

\section{ANTIPROTOZOAN AND ANTI-INFLAMMMATORY ACTIVITIES OF PIPTADENIASTRUM AFRICANUM STEM} BARK

\author{
Omokivie, Peter., ${ }^{1}$ Omisore, Omotayo, ${ }^{2}$ Ogunfiditimi, Dotun ${ }^{2}$ and Ibrahim, Mayowa ${ }^{2}$ \\ and Adewunmi, Clement, 0 . $^{1}$ \\ ${ }^{2}$ Drug Research and Production Unit and Department of Pharmacology, \\ ${ }^{1}$ Faculty of Pharmacy, Obafemi Awolowo University, Ile-Ife, Nigeria.
}

Corresponding author: E-mail: noeowolabi@yahoo.ca, noaomis@ oauife.edu.ng

Background: The development of resistance of the malaria and the trypanosome parasites to the regular drugs has exacerbated the incidences of morbidity and mortality due to the parasites and much attention has been drawn to the utilization of alternative medicine in the management of the disease. African trypanosomiasis is an infectious disease of humans and animals of similar aetiology and epidemiology.

Materials and Methods: Piptadeniastrum africanum stem bark ethanolic extract was tested for its activity on Plasmodium berghei using the 4-schizonticidal assay and also on Trypanosoma congolese in albino mice using standard bioassay techniques. Hot plate, tail flick and acetic-induced writhing models were used to access the analgesic property. The anti-inflammatory and the immunosuppressive assays were also done using the albumin-induced paw oedema and delayed type hypersensitivity methods.

Results: The ethanolic extract exhibited remarkable and dose-dependent antiplasmodial activity, with $100 \%$ chemosuppression at $150 \mathrm{mg} / \mathrm{kg}$. It was able to sustain the treated animals in antitrypanosomal assay. It also demonstrated notable analgesic activity, comparing favourably with the reference drugs (26.44 secs compared to 9.43 and 9.52 secs for acetylsalicylic acid and pethidine respectively in the hot plate method). It inhibited inflammation in the models considerably (79-90\% with $150 \mathrm{mg} / \mathrm{kg}$ ).

Conclusion: The stem bark extract of $P$. africanum can thus be said to have potentials for the treatment of these infections. 


\title{
WANNPRES 2014 ABSTRACTS Afr J Tradit Complement Altern Med. (2015) 12(S):1-44 http://dx.doi.org/10.4314/ajtcam.v12i5.1S
}

EFFECT OF SOLVENTS ON THE ANTI-SICKLING ACTIVITIES OF THREE KHAYA SPECIES

\author{
Ololade O. Oyedapo and Joseph M. Agbedahunsi \\ Drug Research and Production Unit, Faculty of Pharmacy, Obafemi Awolowo University, Ile Ife, Nigeria \\ "Corresponding author: Email: jagbedah@oauife.edu.ng,, Tel: +2348034093508
}

\begin{abstract}
Introduction: Three Khaya species namely K. senegalensis (K.s), K. grandifololia (K.g) and K. ivorensis (K.i) are found along the Western Africa sub- region and they are all called Oganwo by the Yoruba speaking people of South Western Nigeria. In spite of the plants being morphologically different they are all commonly called African mahogany. Their anti-plasmodial activities had been ranked in this order: K. ivorensis $>K$. grandifoliola $>K$. senegalensis. : In an earlier report we found out that different extraction solvent had effect on the anti-plasmodial activities on $K$. grandifoliola stem bark extrac A previous study had reported the antisickling activity of $K$. senegalensis. Therefore, this study was designed to rank the anti-sickling activities and determine the effect of different extraction solvents on the anti-sickling activity of the three Khaya species.
\end{abstract}

Methodologyt water, ethanol and petroleum spirit were used to extract the stem bark of the three Khaya species. The different extracts were subjected to in vitro inhibitory and reversal antisickling activities. Para hyroxy benzoic acid (PABA) and vanillic acid were used as standard control drugs. Sodium metabisulphite was used to induce hypoxial (de-oxygenation) state in the medium and the percentage sickling of the HbSS red blood cells was determined.

Results: The results showed that hot extraction was better than the cold extraction in all the solvent used. The anti-sickling activities were concentration dependent in all cases from $0.5-4.0 \mathrm{mg} / \mathrm{ml}$. The three Khaya species gave better inhibitory activities than reversal activitywhile Khaya ivorensis hot ethanolic extract gave $80.71 \%$ and the reversal gave $41.61 \%$. The ethanolic extract was the best followed by water extract and then petroleum spirit extract i.e. $80.71 \%>69.68 \%>39.37 \%$ for $K$. ivorensis respectively, $65.55 \%>$ $62.79 \%>38.0 \%$ for $K$. grandifoliola and $51.77>49.02>35.24 \%$ for $K$. senegalensis all at $4.0 \mathrm{mg} / \mathrm{ml}$. The para-hydroxyl benzoic acid (PHBA) gave $62.79 \%$

Conclusion: Khaya species have antisickling activities which is ranked in this order: $\mathrm{Ki}>\mathrm{Kg}>\mathrm{Ks}$

\section{P-23}

\section{ANTISICKLING STUDIES ON THREE NIGERIAN MEDICINAL PLANTS}

\author{
Cyril-Olutayo* C. M. and Agbedahunsi J. M.
}

Drug Research and Production Unit, Faculty of Pharmacy, OAU, Ile-Ife.

*Corresponding author: Email: mojiolutayo@gmail.com; Tel: +2348034093508

Introduction: Sickle cell anaemia is an inherited chronic disease in which the red blood cells (RBS) become crescent shaped instead of disc-shaped. It is a genetic disease caused by abnormal haemoglobin called sickle haemoglobin (HbS), which polymerizes under deoxygenated condition and deforms the red blood cells into a 'sickle' shape. In Nigeria and most parts of the developing world, medicinal plants have been used in the treatment of painful crises associated with sickle cell disorder (SCD) especially among the lower socio-economic class who cannot afford the high cost of management required in western medicine. Also being very prevalent in the tropics, patients still depend mostly on ethnomedicinal management of the disorder. 


\title{
WANNPRES 2014 ABSTRACTS Afr J Tradit Complement Altern Med. (2015) 12(S):1-44 http://dx.doi.org/10.4314/ajtcam.v12i5.1S
}

Methodology: The antisickling properties of the ethanolic extracts of three medicinal plants viz: Telfairia occidentalis, Cnidoscolus aconitifolius and Moringa oleifera were carried out using nitrogen gas to induce a hypoxic state in vitro. Membrane stability and antioxidant studies were carried out at various concentrations on the three plant extracts.

Results: M. oleifera gave the highest inhibitory $(95.6 \pm 1.414 \%)$ while $T$. occidentalis gave the highest reversal activity $(95.4 \pm 2.470$ $\%)$. T. occidentalis showed a concentration dependent stability result with $53.97 \pm 0.003 \%$ stability at the highest concentration of 300 $\mu \mathrm{g} / \mathrm{ml}$. Moringa oleifera gave $74.0 \pm 0.019 \%$ inhibition to DPPH (2, 2-diphenyl-2-picrylhydrazyl hydrate) radical scavenging with $\mathrm{IC}_{50}$ of $0.588 \pm 0.019 \mathrm{mg} / \mathrm{ml}$.

Conclusion: The results showed T. occidentalis and M. oleifera as candidate plants for the development of remedy for the treatment of sickle cell anaemia.

P-24

\section{ANTIMALARIAL ACTIVITY OF THE LEAF EXTRACT OF UVARIA CHAMAE ALONE AND IN COMBINATION WITH AMODIAQUINE IN MICE}

\author{
Adepiti A. O. and Akinrinade B. D. \\ Department of Pharmacognosy, Obafemi Awolowo University, Ile-Ife, NIGERIA
}

Background: The practice of combining plant extracts with orthodox drugs is an emerging discipline aimed at proposing alternative drug combinations in antimalarial therapy. This study evaluated the antimalarial potentials of the combination of Uvaria chamae P. Beauv. (Annonaceae) leaf and amodiaquine (AQ), with a view to determining possible interaction that could be beneficial in antimalarial therapy

Method: The powdered leaf was extracted with methanol and concentrated in vacuo at $40{ }^{\circ} \mathrm{C}$. The antimalarial activity of $U$. chamae extract (UCL) against chloroquine (CQ)-sensitive Plasmodium berghei (NK 65 strain) infected mice was evaluated with a twice-daily oral drug administration at $100-800 \mathrm{mg} / \mathrm{kg}$ using the four-day chemosuppressive model. The combinations (UCL+AQ [mg/kg]): $100+5,200+5,400+5$ and 400+10, were similarly assessed in both the CQ-sensitive and -resistant Plasmodium strains (P. berghei ANKA), respectively. AQ $(10 \mathrm{mg} / \mathrm{kg})$ and $10 \%$ Tween- 80 solution were employed as the positive and negative controls, respectively.

Result: At $800 \mathrm{mg} / \mathrm{kg}$, the chemosuppressive activity obtained for the extract was $51.50 \%$. The combination at $200+5 \mathrm{mg} / \mathrm{kg}$ gave chemosuppression of $91.66 \%$, which was significantly higher $(\mathrm{p}<0.05)$ than AQ with activity of $85.41 \%$. In the treatment of CQresistant $P$. berghei, the combination gave $45.80 \%$, which was significantly lower $(\mathrm{p}<0.05)$ than the activity of AQ $(78.40 \%)$.

Conclusion: It can be concluded that the leaf extract and its combination with amodiaquine had better chemosuppressive antimalarial activity at low doses in chloroquine-sensitive murine malaria. 
WANNPRES 2014 ABSTRACTS Afr J Tradit Complement Altern Med. (2015) 12(S):1-44 http://dx.doi.org/10.4314/ajtcam.v12i5.1S

\title{
P-25
}

\section{SEDATIVE AND ANXIOLYTIC EFFECTS OF THE METHANOLIC EXTRACT OF THE LEAVES OF ALCHORNEA LAXIFLORA IN MICE.}

\author{
Nnamdi Nwonu ${ }^{1}$, Olapade Ilesanmi ${ }^{1}$, *Gbola Olayiwola ${ }^{2}$. \\ ${ }^{1}$ Department of Pharmacology; \\ ${ }^{I}$ Department of Clinical Pharmacy and Pharmacy Administration, Faculty of Pharmacy, Obafemi Awolowo University, Ile-Ife, \\ Nigeria.
}

* Corresponding author: gbolayiw@ oauife.edu.ng_Tel: 08037115758

Background: Alchornea laxiflora is a plant used ethnomedically in the management of a variety of systemic disorders including anxiety, insomnia and hypertension, but the pharmacologiacal properties have not been scientifically evaluated. The study investigated the possible activities of the methanolic leaf extract (ALM) of A. laxiflora on central nervous system in mice.

Methods: ALM was tested for sedative, hypnotic and anxiolytic activities, as well as the mechanism(s) underlying the observed neuropharmacological effects. This was done using the open-field maze, hole board, pentobarbital-induced sleep, elevated plus-maze (EPM). Specific antagonists, such as atropine, flumazenil, naloxone and yohimbine were also employed to elucidate the receptors and the mechanisms involved.

Results: Administration of ALM significantly (p < 0.05) and dose- dependently (200, 400, 800, 1600, $3200 \mathrm{mg} / \mathrm{kg}$, i.p.) inhibited novelty-induced rearing (NIR), grooming, locomotion, exploratory activity, as well as prolongation of sleep latency $(800 \mathrm{mg} / \mathrm{kg}$, i.p.) and total sleeping time $(200,400,800 \mathrm{mg} / \mathrm{kg}$, i.p.). ALM also demonstrated anxiolytic activity by increasing the frequency of entry and time spent in the open arms of the EPM and a reduction in the index of open arm avoidance. Pretreatment of ALM with atropine $(0.5 \mathrm{mg} / \mathrm{kg}$, i.p) and yohimbine $(1 \mathrm{mg} / \mathrm{kg}$, i.p.) significantly $(\mathrm{p}<0.05)$ blocked the inhibitory action of ALM on NIR. Pretreatment with naloxone (1 mg/kg, i.p.) and flumazenil (2 mg/kg, i.p.) did not prevent ALM-induced inhibitory action on NIR, rather they enhanced the reduction in NIR.

Conclusion: The results of this study indicate that ALM possesses central effects, and that the sedative and anxiolytic activities may be related to a blockade of adrenergic and cholinergic neurotransmission. 
WANNPRES 2014 ABSTRACTS Afr J Tradit Complement Altern Med. (2015) 12(S):1-44

http://dx.doi.org/10.4314/ajtcam.v12i5.1S

ORGANIZING COMMITTEE:

LOCAL:

Clement O. Adewunmi - Chairman

Joseph M. Agbedahunsi

Hassan Subar

Felix Olorunmola

Francis Oladimeji

Christianah A. Elusiyan

Gbola Olayiwola

Sam Etatuvie

Francis Adewoyin

ECOWAS Rep.

\section{SCIENTIFIC COMMITTEE:}

Abiodun Ogundaini - Chairman

Francis Oladimeji

Clement A. Adebajo

Ezekiel O. Iwalewa

Joseph M. Agbedahunsi

Peter. Akah

Clement O. Adewunmi

Shingu K. Gamaniel

Moses A. O. Akanmu

John A. O. Ojewole

MEETING SECRETARIAT:

WANNPRES Office

Drug Research \& Production Unit

Faculty of Pharmacy

Obafemi Awolowo University

Ile-Ife, Nigeria.

E-mail: wannpres2012@gmail.com

\section{INTERNATIONAL:}

Bonaventure Ngadjui (Cameroon)

David Obiri Danso (Ghana)

Dr Yessé Z. Nanga (Côte d'Ivoire)

Rokia Sanoga (Mali)

Kobus Eloff (South Africa)

Hassanata Millogo (Burkina Faso)

Berhanu Abegaz (Kenya)

Kofi Busia (WAHO)

S. Ouédraogo (Burkina Faso)

ACKNOWLEDGEMENTS: West African Health Organization, African Journal of Traditional, Complementary and Alternative Medicines, NIPRD, AIT, Third World Academy of Sience.

Telephone Numbers:

+2348077492953 